Tom LXXXI - 2020

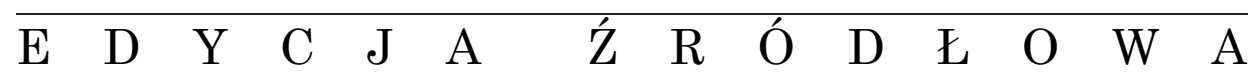

JOANNA PISULIŃSKA

https://orcid.org/0000-0002-1905-8005

Uniwersytet Rzeszowski

\title{
RZECZ O PRZYJAŹNI I NAUCE HISTORYCZNEJ. LISTY FRANCISZKA BUJAKA DO STANISŁAWA ZAKRZEWSKIEGO W ZBIORACH BIBLIOTEKI ZAKEADU NARODOWEGO IM. OSSOLIŃSKICH WE WROCŁAWIU
}

Zarys treści: Prezentowana poniżej korespondencja wybitnego historyka dziejów społeczno-gospodarczych Franciszka Bujaka (1875-1953) obejmuje 30 listów i kartek do Stanisława Zakrzewskiego (1873-1936), znanego i cenionego historyka dziejów Polski, jego wieloletniego przyjaciela i współpracownika. Zostały one wysłane w latach 1902-1933 i dotycza głównie spraw prywatnych, osobistych, ale i również naukowo-organizacyjnych. Prezentowany zbiór listów pochodzi z zasobów Biblioteki Zakładu Narodowego im. Ossolińskich we Wrocławiu.

The content outline: The edited correspondence of Franciszek Bujak (1875-1953), a prominent expert in social and economic history, includes 30 letters and postcards addressed to Stanisław Zakrzewski (1873-1936), a well-known and highly esteemed researcher of Polish history and Bujak's long-time friend and collaborator. The mail dates back to the years 1902-1933 and primarily concerns private matters, although it also contains some discussions of scientific and organizational issues. The discussed material is stored in the Library of the National Ossolineum Institute in Wrocław.

Słowa kluczowe: Franciszek Bujak, Stanisław Zakrzewski, Uniwersytet Jagielloński, Uniwersytet Jana Kazimierza we Lwowie

Keywords: Franciszek Bujak, Stanisław Zakrzewski, Jagiellonian University, John Casimir University in Lviv

Postać Franciszka Bujaka jest dobrze znana. Zadbali o to zarówno jego współpracownicy i uczniowie, będacy pod niemałym urokiem swego mistrza, jak i późniejsi badacze dziejów społeczno-gospodarczych, chętnie czerpiacy z jego bogatego dorobku naukowego, i w końcu historycy 
historiografii, skwapliwie ukazujący wyjątkową rolę Bujaka w rozwoju polskiej nauki historycznej ${ }^{1}$.

Prezentowane poniżej listy Franciszka Bujaka (1875-1953) do Stanisława Zakrzewskiego (1873-1936) ${ }^{2}$ dotyczą długiego okresu życia

${ }^{1}$ Por m.in. S. Inglot, Badania z zakresu dziejów społecznych $i$ gospodarczych $w$ Polsce 1918-1930, „Wiadomości Historyczne” 1933, nr 2, s. 81-111, 153-178; tenże, Franciszek Bujak. Działalność naukowa i dydaktyczna, Wrocław 1955; H. Madurowicz-Urbańska, Franciszek Bujak - o nowy kształt historii, w: F. Bujak, Wybór pism, t. 1, Warszawa 1976 (wyd. 2, Kraków 2001); taż, Franciszek Bujak 1875-1953, w: Uniwersytet Jagielloński. Złota Księga Wydziału Historycznego, red. J. Dybiec, Kraków 2000, s. 208-211; A.F. Grabski, Franciszek Bujak $i$ historia gospodarcza (uwagi o metodologicznych pogladach uczonego), „Historyka” 9, 1979, s. 101-124; A.K. Shelton, The Democratic Idea in Polish History and Historiography: Franciszek Bujak (1875-1953), Boulder 1989; T. Pawelec, Trzy wizje dziejów - F. Bujak, M. Handelsman, J. Rutkowski, w: Środowiska historyczne II Rzeczypospolitej, cz. 5, red. J. Maternicki, Warszawa 1990, s. 166-186; P. Franaszek, Bujakowska koncepcja badania dziejów gospodarczych ziem polskich „Badania z Dziejów Społecznych i Gospodarczych” i Informator statystyczny do dziejów spoteczno-gospodarczych Galicji, w: Celem nauki jest człowiek... Studia z historii społecznej i gospodarczej ofiarowane Helenie Madurowicz-Urbańskiej, Kraków 2000, s. 37-46; A. Janeczek, Franciszek Bujak: historyk w nurcie $\dot{z} y c i a$, w: F. Bujak, Studia nad osadnictwem Matopolski, Poznań 2001, s. 207-233; Z. Budzyński, Szkoła historii społeczno-gospodarczej Franciszka Bujaka na Uniwersytecie Jana Kazimierza we Lwowie, w: Wielokulturowe środowisko historyczne Lwowa w XIX $i$ XX w., t. 2, red. J. Maternicki, L. Zaszkilniak, Rzeszów 2004, s. 309-328; tenże, Franciszek Bujak (1875-1953), w: Złota ksiega historiografii lwowskiej XIX i XX wieku, red. J. Maternicki, współpr. L. Zaszkilniak, Rzeszów 2007, s. 421-440; H. Wójcik-Łagan, Franciszek Bujak jako dydaktyk historii, w: Wielokulturowe środowisko historyczne Lwowa..., s. 500-510; B. Szafraniec, Franciszek Bujak (1875-1953). Życie, działalność naukowo-dydaktyczna i społeczna, Toruń 2009.

2 Szerzej zob. P. Dąbkowski, Profesor Stanisław Zakrzewski. Jego praca $w$ Towarzystwie Naukowem Lwowskiem, „Sprawozdanie Towarzystwa Naukowego we Lwowie" 1936, nr 1, s. 99-108; T.E. Modelski, Działalność naukowa Ś.p. Stanisława Zakrzewskiego, Lwów 1936; K. Tyszkowski, Stanisław Zakrzewski (Wspomnienia pośmiertne), „Nowe Czasy” 1936, nr 6, s. 3; B. Włodarski, Zarys biograficzny (Stanisława Zakrzewskiego), w: S. Zakrzewski, Zagadnienia historyczne, t. 1, Lwów 1936, s. VII-XVI; S. Zajaczkowski, Stanistaw Zakrzewski 1873-1936, „Ateneum Wileńskie” 1936, s. 905-944; J. Adamus, Stanisław Zakrzewski wobec problemu ideologii ustrojowej, „Przewodnik Historyczno-Prawny” 1937, s. 73-78; M. Handelsman, Stanistaw Zakrzewski 1873-1936, „Droga” 16, 1937, s. 420-430; K. Śreniowska, Stanistaw Zakrzewski. Przyczynek do charakterystyki pradów ideologicznych $w$ historiografii polskiej 1893-1936, Łódź 1956; J. Tyszkiewicz, Stanisław Zakrzewski byt nie tylko mediewista, w: Środowiska historyczne II Rzeczypospolitej, cz. 3, red. J. Maternicki, Warszawa 1989, s. 119-131; K. Błachowska, Stanisław Zakrzewski (1873-1936), w: Złota księga historiografii lwowskiej..., s. 379-397; J. Maternicki, U progu niepodległości, w: tenże, Historia i życie narodu. Poglady i postawy historyków polskich XIX i XX w., Rzeszów 2009, s. 304-314; J. Pisulińska, Zagadnienie syntezy w refleksji metodologicznej i dziejopisarstwie Stanisława Zakrzewskiego, w: Badacze przeszłości wobec 
przyjaciół, znacznie uzupełniając charakterystykę ich autora. Pierwszy z zachowanych listów został wysłany w 1902 r. z Genui, ostatni w 1933 r. ze Lwowa. Przyjaźń ta zrodziła się w czasie studiów uniwersyteckich w Krakowie. Jak wspominał S. Zakrzewski, po raz pierwszy „zbliżył się” do Bujaka w 1895 r., a głównym miejscem ich spotkań miały być zebrania członków stowarzyszenia „Zjednoczenie”, skupiające „postępową" młodzież, reprezentująca poglądy socjalistyczne. Jego trzon stanowili studenci przybyli z zaboru rosyjskiego, tzw. Królewiacy (m.in. Zakrzewski) ${ }^{3}$. Miejscem jednakże szczególnym ich spotkań i zarazem współpracy było seminarium historyczne prowadzone przez Wincentego Zakrzewskiego i Stanisława Smolkę ${ }^{4}$. Obaj przyszli historycy bardzo cenili przede wszystkim Smolkę za umiejętności dydaktyczne, ale i również za wprowadzenie do badań historycznych, dzięki zapoznaniu z metodą historyczna „w sposób najbardziej bezpośredni” - jak pisał Bujak ${ }^{5}$. Obaj też byli mu ogromnie wdzięczni za pomoc w uzyskaniu stypendium zapewniajacego im „skromny byt i możność studiów w uniwersytecie" w trudnych studenckich czasach ${ }^{6}$.

Dla Bujaka czas studiów był przede wszystkim okresem poszukiwań odpowiedniego dla siebie pola badawczego, tzn. takiego, który z jednej strony byłby dla niego interesujący, ale i satysfakcjonujący, ze względy na swe nowatorstwo i oddziaływanie społeczne. Świadectwem tych rozterek był wybór zajęć proponowanych przez profesorów Uniwersytetu Jagiellońskiego. Uczęszczał na wykłady Bolesława Ulanowskiego z historii prawa, Mariana Sokołowskiego zajmującego się historią kultury, Józefa Kleczyńskiego, pod kierunkiem którego zainteresował się statystyka, i przede wszystkim Franciszka Czernego-Schwarzenberga, zachęcającego go do badań nad geografią i etnografią.

Pierwszym przedmiotem jego naukowych zainteresowań była historia geografii. W 1899 r. obronił doktorat na Uniwersytecie Jagiellońskim pt. Geografia w Polsce od poczatków XVI wieku. Również później wielokrotnie powracał do tematyki geograficzno-historycznej, m.in. w 1903 r.

wyzwań XIX-XXI wieku, red. K. Błachowska, Z. Romek, M. Wolniewicz, Warszawa 2013, s. 213-227.

${ }^{3}$ Zakład Narodowy im. Ossolińskich we Wrocławiu (dalej: ZNiO), Papiery Stanisława Zakrzewskiego, t. 9. Materiały dotyczące działalności naukowej, społecznej i politycznej Stanisława Zakrzewskiego. Lata 1892-1935, rkps Ossol. 7351/II, k. 7; F. B[ujak], Drogi mojego rozwoju umystowego, „Nauka Polska. Jej Potrzeby, Organizacja i Rozwój” 6, 1927, s. 100-101.

${ }^{4} \mathrm{ZNiO}$, Papiery Stanisława Zakrzewskiego, t. 9, k. 7.

${ }^{5}$ F. B[ujak], Drogi mojego rozwoju umystowego..., s. 97.

${ }_{6} \mathrm{ZNiO}$, Papiery Stanisława Zakrzewskiego, t. 9, k. 7; F. B[ujak], Drogi mojego rozwoju umystowego..., s. 103. 
wydał studium geograficzne $O$ średniowiecznych mapach żeglarskich, którego podstawą były poszukiwania archiwalne i biblioteczne we Włoszech i w Niemczech. Temat ten nurtował Bujaka przez wiele lat, ale nie tylko. W tym okresie podjął również badania nad dziejami społeczno-gospodarczymi. Zainteresowania te były asumptem do wybrania studiów zagranicznych (od listopada 1901 do czerwca 1902 r. brał udział wykładach i seminariach profesorów Uniwersytetu w Lipsku, m.in. geografa Friedricha Ratzela, historyka dziejów kultury i gospodarki Karla Lamprechta, ekonomisty Karla Büchera), ale i samodzielnych poszukiwań archiwalnych i bibliotecznych we Włoszech (Genua, Piza, Florencja, Rzym) i Niemczech (Lipsk i Monachium). W 1905 r. Bujak opublikował „pomnikowa pracę” pt. Studia nad osadnictwem Matopol$s k i$, która stała się podstawą jego habilitacji uzyskanej na Uniwersytecie Jagiellońskim ${ }^{7}$.

Stanisław Zakrzewski z kolei pozostał przy badaniach nad średniowieczem. Jednak ze względu na zły stan zdrowia Smolki szukał wsparcia naukowego u Stanisława Krzyżanowskiego, Bolesława Ulanowskiego i Karola Potkańskiego. Ten pierwszy stał się promotorem jego pracy doktorskiej pt. Najdawniejsze dzieje klasztoru cystersów w Szczyrzycu (1238-1382). Przyczynek do osadnictwa na Podhalu, która obronił w 1900 r. Trzy lata później uzyskał veniam legendi w zakresie historii Polski i średniowiecznej historii powszechnej na podstawie pracy Opactwo benedyktyńskie św. Bonifacego i św. Aleksego na Awentynie w latach 977-1085.

Po uzyskaniu habilitacji obaj historycy podjęli starania o odpowiednie zatrudnienie, zapewniające im utrzymanie. Ostatecznym miejscem ich życia i pracy stał się Lwów. Najpierw przeprowadził się do niego Zakrzewski z żoną i trójką dzieci. W 1905 r. został zatrudniony jako docent na Uniwersytecie Lwowskim. Wykładał nauki pomocnicze historii, historię Polski i średniowieczną powszechna. Dwa lata później otrzymał stanowisko profesora nadzwyczajnego historii Polski. Profesurę zwyczajną uzyskał w 1913 r. Bujak dołączył do Zakrzewskiego w wolnej Polsce, wcześniej będąc docentem i profesorem nadzwyczajnym Uniwersytetu Jagiellońskiego i krótko profesorem zwyczajnym na Uniwersytecie Warszawskim. Niedługo zajmował też stanowisko ministra rolnictwa w pierwszym rządzie Władysława Grabskiego. W 1920 r. Zakrzewski, pełniąc wówczas funkcję dziekana Wydziału Filozoficznego Uniwersytetu Lwowskiego, namówił Bujaka do przyjęcia propozycji objęcia we Lwowie Katedry Historii Społeczno-Gospodarczej. Bujak kierował nią

\footnotetext{
${ }^{7}$ S. Inglot, Franciszek Bujak. Działalność..., s. 6.
} 
przez 19 lat (od 1920 do 1939 r.), tworząc we Lwowie najważniejszy ośrodek badań historyczno-gospodarczych w Polsce i tym samym stając się, właśnie obok Zakrzewskiego, najważniejszą postacią studium historycznego na UJK w okresie międzywojennym.

Bujak i Zakrzewski zaangażowali się też w życie pozauniwersyteckie, zwłaszcza w działalność Polskiego Towarzystwa Historycznego i Towarzystwa Naukowego we Lwowie. Nie będzie więc też przesadą nazwanie tych historyków pierwszoplanowymi, majacymi największy wpływ na kształt i rozwój całego lwowskiego środowiska historycznego.

$$
* \quad * \quad *
$$

Prezentowane listy znajdują się w przechowywanej w Dziale Rękopisów Biblioteki Zakładu Narodowego im. Ossolińskich we Wrocławiu korespondencji Stanisława Zakrzewskiego (rkps Ossol. 7343/II). Zbiór ten obejmuje 30 listów, 3 pocztówki i bilecik. W pierwszym z nich brakuje daty dziennej. Wiadomo jednakże, że został on napisany w 1902 r., podczas pobytu Bujaka w Genui; ostatni został wysłany 27 V 1933 r. Pominięto pocztówki i bilecik, zawierają one krótkie pozdrowienia i życzenia.

Listy są ułożone w porządku chronologicznym. W przeważającej części mają one charakter prywatny. Franciszek Bujak informował przyjaciela o sprawach osobistych, dotyczących swych najbliższych, o przebiegu kariery naukowej, o nowo napisanych rozprawach. Ukazuja one również stosunek Bujaka do metod pracy naukowej i potwierdzaja jego sumienność, rzeczowość oraz silną potrzebę konfrontowania wyników swych badań z przedstawicielami innych dyscyplin naukowych. Historyk poruszał też kwestie dotyczące spraw uniwersyteckich i związane $\mathrm{z}$ działalnościa $\mathrm{w}$ towarzystwach naukowych. W zachowanej korespondencji znajdują się także listy urzędowe. Były one kierowane do Zakrzewskiego jako przewodniczącego komisji przygotowującej reformę studiów historycznych na Uniwersytecie Jana Kazimierza we Lwowie. Są o tyle interesujące, że ukazują zaangażowanie Bujaka w działalność dydaktyczna, ale i funkcjonowanie studium historycznego na Uniwersytecie Lwowskim po wprowadzeniu reformy w $1926 \mathrm{r}$.

Przy przygotowywaniu listów do druku stosowano się do zasad określonych w Projekcie instrukcji wydawniczej dla źródet historycznych XIX i poczatku XX wieku Ireneusza Ihnatowicza („Studia Źródłoznawcze” 7, 1962, s. 99-124). Zgodnie z tym zmodernizowano pisownię i interpunkcję. Wszelkie podkreślenia pochodzą od autora, w nawiasach kwadratowych rozwiązano wszystkie skróty i dodano nieliczne uzupełnienia wydawcy. W przypisach czytelnik znajdzie informacje o sprawach 
i postaciach występujących w listach. Zostały one sporządzone na podstawie literatury przedmiotu oraz wydawnictw słownikowych i encyklopedycznych polskich i zagranicznych.

\section{Listy}

\section{ZNiO, rkps Ossol. 7343/II, k. 271-273}

Kochany Staszku,

W Genui siedzę już 3ci tydzień i niby zajmuję się przeglądaniem rękopisów, ale w gruncie rzeczy tylko próżnowaniem ${ }^{8}$. W każdym razie przed Wielkanocą nie opuszczę Genui, bo nawet jeszcze nie oglądałem tutejszych rzeczy godnych widzenia. Mam okropnie wstrętne uczucie, że marnuję czas, strasznie jestem z tego niezadowolony, ale obawiam się czy będę mógł cośkolwiek robić we Włoszech. Chcę być w Pizie, pierwej nim do Rzymu jechać. Czas strasznie leci, człowiek się starzeje, a nic nie robi i nic nie warta.

Ty przynajmniej może tego roku więcej robisz w Rzymie ${ }^{9}$. Zamierzam z miesiąc posiedzieć sobie w Rzymie. Czy Ci Sobek ${ }^{10}$ posłał swa Nienawiść ttumów ${ }^{11}$. Mnie się nie podoba trochę, bo oprócz sztubackości cytatów na końcu i początku rozdziałów, tudzież zbytniej dramatyczności stylu - nie podoba mi się tytuł i myśl zasadnicza książki. Mianowicie nie przypisuję ludowi naszemu inicjatywy w sprawach religijnych, a tym bardziej wybuchów. Sądzę, że wszystkie rozruchy były mozolnie inspirowane $\mathrm{w}$ miastach, gdzie propaganda protestancka najbardziej mogła być groźna dla duchowieństwa. Co to za nienawiść a ruch ludowy, w którym biora udział przeważnie studenci. Lud mógł mieć niechęć, to jest bardzo zrozumiałe, ale do wybuchu od tego jeszcze daleko.

${ }^{8}$ W 1902 r. Bujak udał się do Włoch w celach naukowych dzięki otrzymanemu stypendium Fundacji Seweryna Gałęzowskiego.

${ }^{9}$ Stanisław Zakrzewski przebywał w Rzymie do lata 1902 r. w ramach Ekspedycji Rzymskiej Akademii Umiejętności.

${ }_{10}$ Wacław Sobieski (1872-1935), historyk, badacz dziejów nowożytnych. Studiował w latach 1892-1896 na Wydziale Filozoficznym Uniwersytetu Jagiellońskiego, wspólnie w Bujakiem i Zakrzewskim. W 1900 r. uzyskał doktorat, następnie w 1908 r. habilitację z zakresu historii powszechnej. W 1910 r. otrzymał stanowisko profesora nadzwyczajnego UJ, w 1913 r. został profesorem zwyczajnym. W 1935 r. przeszedł na emeryture w związku z likwidacja, z przyczyn politycznych, kierowanej przez niego katedry.

${ }_{11}$ Pełny tytuł pracy W. Sobieskiego brzmi: Nienawiść wyznaniowa tłumów za rzqdów Zygmunta III-go i opublikowana została w 1902 r. Sobieski usiłował w niej dowieść, że kontrreformacja w Polsce była wynikiem działań mas ludowych. 
We włoszczyźnie bardzo słabo postępuję. Rozmowa mi idzie bardzo tępo, a nie sadzę się także na napisanie do Ciebie po włosku. Obecnie przyjechało tu troje znajomych z Zurychu i zabierają mi czas, tak że już nic robić nie mogę - a to mnie irytuje.

Bardzo jestem kontent, że mi ułatwisz tanie urządzenie się, tutaj również tanio się urządziłem, zupełnie tak, jak ty mi obiecujesz. Mieszkam tuż nad morzem w Sturli ${ }^{12}$, o kilka kilometrów od miasta, do którego jeżdżę tramwajem.

Morze jest przyjemne, gdy jest ciche, gdy całą noc hałasuje, to człowiekowi się uprzykrzy jak dziecko.

Zresztą ściskam Cię serdecznie i zasyłam ukłony Żonie ${ }^{13}$ i moje pa! córce $^{14}$

Twój Franek

\section{ZNiO, rkps Ossol. 7343/II, k. 275-276}

Zakopane, Knoblanchówka, 24 III 1903 r.

\section{Kochany Staszku,}

$\mathrm{W}$ niedzielę posłałem rękopis pracy o mapach żeglarskich ${ }^{15}$ równocześnie z listem do prof. Ul[anowskiego] ${ }^{16} \mathrm{z}$ prośbą o rozpoczęcie druku jak najprędsze. Proszę Cię bardzo, abyś mi był łaskaw donieść, jakie są widoki na to rozpoczęcie druku to znaczy, jak się przedstawia stan druku Rozpraw Wydziału Histor[ycznego] i czy prof. Ul[anowski] nic nie mówił o moim rękopisie? - U mnie nic osobliwego, kuruje się, to znaczy: jem setnie jak to potrafię i włóczę się po Zakopanem. Za to drugie suchoty w kieszeni - dochody do przerażających rozmiarów. Choćby dla tego samego - proszę Cię gorąco, abyś, ile to od Twojej chęci i gorliwości popierania nauki w ogóle, a mnie specjalnie zależy - starał się o rozpoczęcie tego druku. Co by to była za cudowna rzecz, gdybym tak

${ }^{12}$ Dzielnica Genui.

13 Żoną Zakrzewskiego od 1897 r. była Sydonia z domu Bitmar.

${ }^{14}$ Córka Wanda, ur. 16 II 1899 r., późniejsza żona lekarza i asystenta Wydziału Lekarskiego UJK we Lwowie dr. Romana Eplera.

${ }_{15}$ F. Bujak, O średniowiecznych mapach żeglarskich, Kraków 1903. Praca ukazała się w wydawnictwie Akademii Umiejętności.

16 Bolesław Ulanowski (1860-1919), historyk prawa i mediewista, od 1888 r. profesor nadzwyczajny prawa polskiego i kanonicznego na Uniwersytecie Jagiellońskim, od 1890 r. profesor zwyczajny. W latach 1903-1919 sekretarz generalny Akademii Umiejętności. 
za 4 tygodnie od daty niniejszej mógł pobrać wynagrodzenie za 4 arkusze druku!

Załączam ukłony Twojej Żonie i ściskam Cię

Proszę o wczesną odpowiedź!

Franek

3. ZNiO, rkps Ossol. 7343/II, k. 277-280

[Kraków], 8 XII 1904 r.

Kochany Staszku,

Sprawił mi naprawdę wiele przyjemności Twój list pełen szczerości i uczucia, nie przypuszczałem nawet, że potrafisz tak do mnie napisać, a wiesz, że to bardzo cenię.

Stało się to i dla nas wiadomym, coś się Ty dowiedział w Wiedniu w październiku, że dostajesz renumerację we Lwowie jako docent nauk pomocniczych ${ }^{17}$. Wprawdzie zrobili to po austriacku, jak tylko sobie można wyobrazić, bo nie dotrzymali terminu, nie dali Ci tytułu profesora nadzwyczajnego, który ich przytem nic nie kosztował, ale sądzę, że i tak trzeba Ci pogratulować, w każdym razie bowiem jest to już pewne, że za 2 lata najdalej, a może i wcześniej normalnym nadzwyczajnym profesorem zostaniesz ${ }^{18}$. Prawdopodobnie więc letni semestr spędzisz w Krakowie.

Podoba mi się p. Okunia' ${ }^{19}$ Skrzypek wystawiony tu w Krakowie (niezupełnie jednak, głównie ze względu na 3 postacie siedzące). Chciałbym mieć jego adres, może bym zapytał się o cenę, gdyby zwłaszcza żonie ${ }^{20}$

17 Zakrzewski rok po uzyskaniu w 1903 r. veniam legendi otrzymał tzw. renumerowaną docenturę na Uniwersytecie Lwowskim. W 1905 r. rozpoczął wykłady z nauk pomocniczych historii oraz historii polskiej i średniowiecznej powszechnej. W swej krótkiej autobiografii narzekał: „trzeba było iść do Lwowa na 2000 koron rocznie z Rodzina, a to z żoną i trojgiem dzieci”; ZNiO, Papiery Stanisława Zakrzewskiego, t. 9, k. 11.

${ }_{18}$ Bujak miał rację, w 1907 r. Zakrzewski otrzymał stanowisko profesora nadzwyczajnego historii Polski na Uniwersytecie Lwowskim.

19 Edward Okuń (1872-1945), polski malarz modernista i ilustrator. Od 1898 r. przebywał w Rzymie. W 1921 r. zamieszkał w Warszawie, od 1925 r. był profesorem w Szkole Sztuk Pięknych im. W. Gersona. Swe dzieła wystawiał m.in. w Krakowie (m.in. w 1904 i 1905 r.) i we Lwowie (m.in. w 1901 r.). Bujak wspomniał zapewne o jego obrazie Filistrzy (Skrzypek) z 1904 r. Obecnie znajduje się on w zbiorach Lwowskiej Galerii Obrazów.

${ }^{20}$ Ewa Kramsztyk (1879-1909) wywodziła się z asymilowanej rodziny żydowskiej. Żoną Bujaka została w 1903 r., po wcześniejszym przyjęciu chrztu. 
się obraz spodobał, atoli dzięki nieustalonemu zdrowiu nie miała jeszcze sposobności oglądania go.

Czy tam w Archiwum ${ }^{21}$ nie pracuje przypadkiem Dr Franz Arens ${ }^{22}$, Niemiec z Pragi, rudawy, wcale poczciwy chłop, mój kolega z Lipska. Gdybyś go tam poznał pozdrów go ode mnie; w pierwszych dniach listopada posłał mi kartkę z Rzymu.

Córka ${ }^{23}$ wcale przykładnie i moralnie się sprawuje, po pewnych nieporządkach obecnie ma się dobrze i coraz więcej jej przybywa na wadze. Zasługuje zwłaszcza na pochwałę za nieurządzanie nocnych awantur.

Co do pisania Wackowego ${ }^{24}$, to będzie to coś bardzo „warszawskiego". Prospekt napisany przez Smoleńskiego ${ }^{25}$ wygląda jak dla pensjonarek dobrze, jak dla historyków niemal licho, dziecinnie. Zresztą nic o nim nie wiem.

$\mathrm{Z}$ wiadomości krakowskich najciekawsze może ciagłe wymyślania Piekosińskiego ${ }^{26}$ na Ulanowskiego i ciagłe umizgi Ulanowskiego do Piekosińskiego. Niechęć do Kutrzeby ${ }^{27}$ u Ulan[owskiego] trwa dalej, do wydawnictwa laudów chce mu wpakować Piekosińskiego ${ }^{28}$.

${ }^{21}$ W 1904 r. Zakrzewski przebywał w Rzymie, pracował w Archiwum Watykańskim, przygotowując do druku depesze Giovanniego Andrei Caligariego, nuncjusza papieskiego w Polsce w latach 1578-1581. Ostatecznie pracy tej nie przygotował. Sam wspominał: „Wobec tego, że byłem wówczas zamianowany wydawcą depesz nuncjusza Caligariego, [...] wyjechałem na zimę 1904 r. ponownie do Rzymu [...]. Zjeździłem wtedy Włochy porządnie, pracowałem intensywnie i przywiozłem na wiosnę 1905 spore nowe materiały": ZNiO, Papiery Stanisława Zakrzewskiego, t. 9, k. 11.

${ }^{22}$ Franz Arens (1880-?), niemiecki badacz historii najnowszej, wydawca źródeł.

${ }^{23}$ Pierwsza córka Bujaków, Ewa Zofia, urodziła się 9 X 1904 r.

${ }^{24}$ Wacława Sobieskiego, zob. przyp. 10.

${ }^{25}$ Władysław Smoleński (1851-1926), historyk dziejów Polski XVIII stulecia, jeden z najwybitniejszych przedstawicieli szkoły warszawskiej w polskiej historiografii. Kończył prawo na Cesarskim Uniwersytecie Warszawskim, podczas zaborów był nauczycielem na pensjach warszawskich. W wolnej Polsce obją stanowisko profesora zwyczajnego historii Polski nowożytnej na UW.

${ }^{26}$ Franciszek Piekosiński (1844-1906) - historyk mediewista, od 1892 r. był dyrektorem Archiwum Krajowego Aktów Grodzkich i Ziemskich w Krakowie i jednocześnie od 1891 r. profesorem historii prawa polskiego na UJ, od 1878 r. członek czynnym Akademii Umiejętności.

${ }^{27}$ Stanisław Kutrzeba (1876-1946), historyk prawa i ustroju, studiował historie i prawo na UJ. W latach 1901-1908 pracował w Archiwum Krajowym Aktów Grodzkich i Ziemskich w Krakowie, w 1908 r. otrzymał stanowisko profesora nadzwyczajnego historii prawa polskiego na Wydziale Prawa UJ, w 1912 r. profesurę zwyczajna. W latach 1926-1939 sekretarz generalny PAU, a w latach 1939-1946 jej prezes.

${ }^{28}$ W 1901 r. na wniosek Ulanowskiego powierzono Kutrzebie zinwentaryzowanie i wydanie odpisów laudów z archiwów warszawskich ze spuścizny Adolfa Pawińskiego, przekazanej Komisji Historycznej AU po jego śmierci. W grudniu 1904 r. na posiedzeniu Komisji Historycznej uchwalono, również na wniosek Ulanowskiego, aby oprócz Kutrzeby przygotowanie wydawnictwa powierzyć prof. Piekosińskiemu. 
W tych dniach było posiedzenie administracyjne Akad[emii] Umiej[ętności] i Komisji różnych. Nie mianowali Ciebie ani nikogo członkiem, bo wszystkie miejsca sa obsadzone. Piekosiński zdaje się miał ochotę stawiać Kutrzeby kandydaturę i ja go do tego zachęcałem.

Co uchwalono na Komisji Hist[orycznej] dowiem się od Kutrzeby jutro.

Żona zasyła Ci piękne ukłony, córka milczy dyskretnie, bo śpi.

Serdecznie Cię całuję

Twój Franek

Proszę o pozdrowienia dla Ptaśnika ${ }^{29}$, p. Okunia, p. Wygrzywalskiego $^{30}$, Grajnerta ${ }^{31}$ itd., i ich żon ma się rozumieć.

Staff $^{32}$ wybiera się na wiosnę do Rzymu, może się jeszcze spotkacie, był tu w Krakowie.

\section{ZNiO, rkps Ossol. 7343/II, k. 281-284}

[Kraków], 27 II 1908 r.

Kochany Staszku,

Z listu Twojego ostatniego wyczytuję przede wszystkim fatalnie podły nastrój. Skwaszony jesteś, współczuję z Tobą szczerze. Racz choć chwilę o tem pomyśleć. Co do kwestii udziału, nie myślałem, że trzeba zaraz spłacić, a zwłaszcza że Ty będziesz musiał wpłacić. Przypuszczam, że

29 Jan Ptaśnik (1876-1930), historyk średniowiecza, kultury polskiej i zachodnioeuropejskiej; w 1903 r. uzyskał doktorat, w 1907 r. przeprowadził na UJ habilitację. W lipcu 1919 r. otrzymał tytuł profesora nadzwyczajnego na UJ, a w grudniu tegoż roku profesurę zwyczajną na UJK we Lwowie. Do 1930 r. kierował tamże Katedra Historii Średniowiecza i Nauk Pomocniczych Historii. Od 1918 r. członek korespondent AU, a od 1929 r. członek czynny PAU. W 1904 r. przebywał w Rzymie w związku z poszukiwaniami archiwalnymi w ramach Ekspedycji Rzymskiej. W tym samym roku podją w Rzymie studia z historii sztuki i archeologii.

${ }^{30}$ Feliks Michał Wygrzywalski (1875-1944), malarz, w latach 1900-1906 przebywał w Rzymie. W 1918 r. osiadł we Lwowie.

${ }^{31}$ Edward Grajnert (1876[1877?]-1907), malarz, w latach 1895-1905 przebywał we Włoszech, m.in. w Rzymie, gdzie malował głównie włoskie pejzaże. W 1903 r. opublikował we Lwowie Artystyczno-informacyjny przewodnik po Rzymie. Zginął w Łodzi podczas walk rewolucji 1905-1907.

${ }^{32}$ Leopold Staff (1878-1957), jeden z najwybitniejszych polskich poetów XX w. Urodził się we Lwowie, w latach 1897-1901 studiował na tamtejszym Uniwersytecie, na wydziałach prawa i filozoficznym. Od 1914 r. mieszkał w Warszawie. 
Ci to będzie ciężko obecnie, więc racz wstrzymać tę sprawę, za parę tygodni upomnę się u Altenberga ${ }^{33}$ o resztę honorarium za I-szy tom Galicji; więc wpłacę cały udział. A tymczasem przyślij numer drugi „Ateneum [Polskie]”34. Jak tylko spłodzę coś inteligentnego, to Ci poślę, ale nie chcę dawać jakiegoś trzeciorzędnego towaru.

Żałuję bardzo, żeś był na te przykrości z Krzyżanowskim ${ }^{35}$ narażony. On przecież i mnie podejrzewał, że powołanie Waszyńskiego ${ }^{36}$ do Lwowa to moja intryga. Nie pisałem Ci tego, bo nie lubię takich małostkowych historii. Krzyżanowski urządził mi przecież taki kawał, że mnie polecał Ćwiklińskiemu ${ }^{37}$ jako kandydata do nowej katedry historii gospodarczej, choć przed paru tygodniami mówiłem mu, że taka katedra nie istnieje na żadnym uniwersytecie austriackim, więc i dla mnie jej nie stworza. Była to po prostu złośliwość. Waszyńskiego popierać na Lwów w żaden sposób nie mogę. Gdyby nawet on tam poszedł, to by to mojej sytuacji nic nie zmieniło. Ja wiem, że wszyscy trzej krakowscy historycy mnie nie cierpią i najprawdopodobniej każdy z nich owego kandydata uplasować zdoła. Ponieważ na geografię moje widoki sa prawie równe zeru, więc jestem zrezygnowany i radbym, aby się ta sprawa albo już rozstrzygnęła definitywnie, albo do mej świadomości nie dochodziła w dalszym toku. Bo przyznam się drażni mię, gdy o tem słyszę lub muszę mówić. Również myślę, że i Twoja życzliwość do mnie i innych ewentualnie nic nie zdoła zmienić, więc trzeba to wykreślić. Czynię to tym łatwiej, że na to miejsce mogę co innego wsadzić. W każdym razie jakiś czas historii poświęcę, aby się z nią rozejść w porządku i bez żalu.

${ }^{33}$ Alfred Altenberg (1877-1924), właściciel lwowskiego wydawnictwa i księgarni.

34 „Ateneum Polskie” - czasopismo literacko-artystyczne, wydawane od $1908 \mathrm{r}$. przez środowisko narodowo-demokratyczne, poświęcone sprawom kultury. Jego redaktorem był Stanisław Zakrzewski.

35 Stanisław Krzyżanowski (1865-1917), historyk mediewista i znawca nauk pomocniczych historii, studiował na UJ, gdzie uzyskał doktorat praw (1887) i filozofii (1888), tam również habilitował się, w 1891 r. otrzymał jako pierwszy w Polsce veniam legendi z zakresu nauk pomocniczych historii. W 1897 r. został profesorem nadzwyczajnym, a w $1905 \mathrm{r}$. profesorem zwyczajnym UJ.

36 Stefan Waszyński (1872-1908), starożytnik, w 1898 r. uzyskał doktorat w Berlinie, w 1905 r. habilitował się na UJ z zakresu historii starożytnej z epigrafiką i papirologią. Był stypendysta AU. Zmarł nagle w 1908 r. w Atenach.

${ }^{37}$ Ludwik Ćwikliński (1853-1942), filolog klasyczny. Studiował na Uniwersytecie Wrocławskim, doktorat obronił w 1873 r. w Berlinie, w latach 1876-1902 był profesorem Uniwersytetu Lwowskiego, w 1902 r. został profesorem w Instytucie Archeologicznym w Wiedniu oraz szefem sekcji szkół wyższych i referentem spraw uniwersyteckich w Ministerstwie Wyznań i Oświaty. 
Stary Z[akrzewski] ${ }^{38}$ pisał z Rzymu wielokrotnie do Ptaśnika, Toka$\mathrm{rza}^{39}$ i Sobieskiego, ale do mnie się nie odezwał.

Sobieski, z którym właśnie mówiłem, powiedział mi, że to co pisał, pisał z życzliwości dla Ciebie. Dziwne tylko dlaczego do Ciebie wprost nie napisał, ja dopiero od niego dzisiaj się o tem dowiedziałem. W każdym razie trudno mi rozstrzygać, czy to ze Lwowa przyniesione rzeczywiście, czy też ukute w Krakowie. Sobieski dowiedział się o tem od Krzyżanowskiego (!?!)

Szczerze Cię ściskam. Radbym kiedy odwiedzić Cię we Lwowie, może przecież znajdzie się jaka okazja, że tam się wybiorę.

Ukłony dla Pani

F. Bujak

PS. Dziś będzie posiedzenie Wydz[iału] Filoz[oficznego], na którym postawi Krzyż[anowski] wniosek o proponow[anie] Waszyńskiego na nadzwyczajnego. Morawski ${ }^{40}$ podobno wymógł na Ćwiklińskim, że W[aszyńskiego] dla Krakowa poprze. Stary Z[akrzewski] wiedział o planie lwowskim w listopadzie, ale nic nie napisał do Krakowa. Gdy dopiero po wymianie listów dowiedzieli się o tem w Krakowie, oburzyli się na Starego i chcieli Kętrzyńskiego ${ }^{41}$ (tj. Krzyżanowski, który się za seniora historyków uważa już) od razu na nadzwyczajnego przyjmować, nawet godzili się na to inni prof[esorowie] członkowie Wydz[iału].

38 Wincenty Zakrzewski (1844-1918), badacz dziejów nowożytnych, w $1871 \mathrm{r}$. uzyskał habilitację na Uniwersytecie Lwowskim, w 1872 r. został profesorem historii powszechnej w Uniwersytecie Jagiellońskim. W 1879 r. mianowany profesorem zwyczajnym historii powszechnej. Od 1884 r. członek czynny AU, wieloletni sekretarz Wydziału Historycznego AU.

${ }^{39}$ Wacław Tokarz (1873-1937), historyk wojskowości, studiował na UJ, w 1902 r. doktoryzował się pod kierunkiem W. Zakrzewskiego, w 1905 r. habilitował się, w latach 1909-1920 profesor zwyczajny na UJ. W latach 1918-1927 kierował Wojskowym Instytutem Naukowo-Wydawniczym. W 1928 r. objął Katedrę Nowożytnej Historii Polski na Uniwersytecie Warszawskim.

${ }^{40}$ Kazimierz Morawski (1852-1925), profesor historii klasycznej na Uniwersytecie Jagiellońskim, od 1887 r. profesor zwyczajny UJ i członek czynny AU, w latach 1918-1925 prezes PAU.

${ }^{41}$ Stanisław Kętrzyński (1876-1950), historyk mediewista, studiował historię na Uniwersytecie Lwowskim, w 1900 r. doktoryzował się na UJ, tam też w 1913 r. uzyskał habilitację w zakresie historii średniowiecza i nauk pomocniczych historii. W 1918-1920 i 1932-1939 pracował na UW, od 1934 r. profesor zwyczajny i kierownik Katedry Historii Polski Wieków Średnich. 


\section{ZNiO, rkps Ossol. 7343/II, k. 285-288}

[Kraków?], 10 IV 1908 r.

Kochany Staszku,

Bardzo serdecznie Ci dziękuję za list ostatni, za jego sympatyczny ton i przyjacielski. Nie wiesz, jaką mi uczyniłeś przyjemność tym, i jak sobie przypominam, kilkoma innymi z ostatniego roku listami. Chwała Bogu, wykopałem się już z biedy, która na szczęście nie pozostawiła na moim nastroju nerwowym żadnych śladów. Obecnie już wstaję, głowę mam prawie zupełnie wolna, ale nogi noszą mię jeszcze licho, chodzę jak starzec. Przypuszczam, że to jednakże szybko przejdzie. Z początku przyszłego tygodnia zamierzam wyjechać na południe na jezioro Garda ${ }^{42}$ lub do Dalmacji na parę tygodni. Dotąd zdecydowani nie jesteśmy. Uczynimy do dopiero w Wiedniu. Kiedy do roboty będę mógł wrócić, nie wiem. Nie jestem pewny wakacji, więc muszę sobie teraz porządnie odpocząć.

Muszę Ci zakomunikować, że mam obecnie konkretna propozycję na urzędnika Wydz[iału] Kraj[owego] do Lwowa (płaca około 3400 złr.). Z drugiej strony dochodza mnie słuchy, że w Wydziale Filoz[oficznym] krak[owskim] powstała opinia, żeby mię mianować nadzwycz[ajnym] profesorem, ale niestety albo bez albo z minimalna renumeracja. Nie wiem, co z tym faktem zrobia historycy, bo od nich musi wyjść propozycja. Nie wiem, co mam zrobić, czy pożegnać się z uniwersytetem i z nauką i przejść na pole pracy społecznej, czy też zostać przy uniwersytecie i 20 lat czekać na pensję zwyczajnego prof[esora]. Nie wiem, czy wyrzeczenie się pracy naukowej nie byłoby dla mnie zbyt ciężkie, czy ja z książkami nie jestem zbyt związany i czy moja praca naukowa nie ma, względnie nie miałaby w przyszłości większej wartości niż praca społeczna. W maju się te rzeczy muszą zdecydować. Może napiszesz Twoje zdanie.

Jak stoi „Ateneum Polskie”? Zdaje mi się, że coraz bardziej jest interesujace, przynajmniej dla mnie w czytaniu. Artykuł Szelagowskiego ${ }^{43}-$ dosyć ciekawy, ale powierzchowny - strasznie i pełny błędów (przypadkowo znam nieco tych spraw $\mathrm{z}$ racji geografii). Sobieski, który mię teraz w chorobie dosyć odwiedzał, posłał Ci swój odczyt

42 Jezioro w północnych Włoszech.

${ }^{43}$ Adam Szelagowski (1873-1961), badacz dziejów nowożytnych, studiował na UJ i Uniwersytecie Lwowskim, w 1900 r. doktoryzował się na UL pod kierunkiem Ludwika Finkla, dwa lata później otrzymał veniam legendi, w 1909 r. tytuł profesora historii średniowiecznej i nowożytnej na UL, w latach 1920-1939 kierował Katedra Historii Powszechnej Nowożytnej (od 1925 r. Historii Nowożytnej). 
o pesy- i optymizmie w historiografii pol[skiej] $]^{44}$. Była o nim szeroka dyskusja profesorska, nie słyszałem oczywiście ani odczytu, ani dyskusji.

Czytałem twoje Zagadnienia ${ }^{45}$ po stronie, tak bym rad mieć przypiski do ostatnich 2 artykułów. Dużo ciekawych myśli.

Ściskam Cię i ukłony dla Pani ślę

F. Bujak

\section{ZNiO, rkps Ossol. 7343/II, k. 291-294}

[Grado, Włochy], 23 VIII 1909 r.

Kochany Staszku,

Tak mi tu trudno ${ }^{46}$ zabrać się do czegokolwiek, że nie dziw się, iż tak późno się odzywam. Jeszcze tego samego dnia z niem[ieckich] gazet dowiedziałem się, żeś mi telegraficznie gratulował nominacji na nadzwycz[ajnego] profesora ${ }^{47}$. Na trzeci dzień miałem już nadesłany dekret przez dziekana i wezwanie do zgłoszenia wykładów. Zastanawiałem się, czy mam jeszcze wdawać się w pertraktacje z Wydziałem Krajowym co do Dublan ${ }^{48}$ etc. Twój telegram i wzgląd na to, że z powodu zdrowia żony potrzebny mi urlop, a w Krakowie łatwiej go dostanę niż w Wydziale Krajowym tudzież niepowodzenia we Lwowie (Patronat, Politechnika) doradzały mi zostać się przy Krakowie. Toteż gdy przedwczoraj dostałem od Mikułowskiego Pomorskiego ${ }^{49}$ telegraficzne zapytanie, czy dalej chcę kandydować, odpowiedziałem, że nie. Gdyby mieli byli czas załatwić ze mną sprawę przed ogłoszeniem nominacji krakowskiej - byłbym na dobrych warunkach poszedł $\mathrm{z}$ chęcia. Teraz uważałbym trochę za nielojalność wobec Krakowa, gdybym dalej o Dublany pertraktował.

Tak tedy lisy nie chciały, bym się na Lwowianina zamienił - jednak nie uważam tego za wykluczone w przyszłości, choćby z tego względu, że nie mam uprzedzeń do Lwowa, ale dużo inklinacji. Teraz przez kilka

${ }^{44}$ W. Sobieski, Optymizm i pesymizm w historiografii polskiej, „Ateneum” 2, 1908.

${ }^{45}$ S. Zakrzewski, Zagadnienia historyczne, Lwów 1908.

${ }_{46}$ Przebywał z żoną we Włoszech.

${ }_{47} 7$ VIII 1909 r. Bujak otrzymał tytuł profesora nadzwyczajnego polskiej i powszechnej historii gospodarczej na Uniwersytecie Jagiellońskim.

${ }^{48}$ Bujakowi zaproponowano zatrudnienie w Akademii Rolniczej w Dublanach pod Lwowem.

49 Józef Mikułowski-Pomorski (1868-1935), w latach 1906-1911 dyrektor Akademii Rolniczej w Dublanach, profesor chemii rolnej. W 1911 r. przeniósł się do Warszawy, był profesorem i pierwszym rektorem Szkoły Głównej Gospodarstwa Wiejskiego w latach 1918-1920. 
lat będę tkwił w historii, może nawet celem badań do Lwowa na kilka miesięcy się wybiorę.

Co do stanu żony, to jest on dotąd lichy, bóle nie zmniejszają się raczej pochodzące z promieni rentgenowskich jeszcze nie doszły do owego kresu rozszerzenia, a kiedy się wyleczą? Te rany (raczej po lekarsku wrzody) są najfatalniejszą komplikacja, wobec której właściwa kuracja schodzi na dalszy plan. A rany są b[ardzo] przykre, bo i chodzić, i spać trudno. Prawdopodobnie dla badania tych ran żona wróci do kraju, a mianowicie do Warszawy, bo jazda do Egiptu z tymi bolesnymi ranami byłaby b[ardzo] trudna. W takim razie ja bym został w Krakowie.

Prosiłbym Cię, abyś podał swój przyszły adres i opisał stan tej realności, ale ogrodu, jaki tam itd..$^{50}$ Jak zapewne wiesz, ja też się nosiłem z planem nabycia domku z ogródkiem lub czego podobnego w Krakowie lub daleko poza Krakowem, na razie oczywiście zawieszam te projekty na kołku. Ja tu średnio się czuję, o pracy prawie nie ma mowy, układ dnia i konieczne pomagania żonie utrudnia to nadzwyczajnie. Ściskam Cię serdecznie, ukłony dla Pani.

Franek $^{51}$.

\section{ZNiO, rkps Ossol. 7343/II, k. 297-298}

[Kraków, początek 1910 r.]

Kochany Staszku,

Dziękuję Ci za tych parę słów przyjacielskich, któreś mi na Nowy Rok przysłał. Ceniłem sobie życzliwość ludzką zawsze, teraz jeszcze

${ }^{50}$ Zakrzewscy w 1909 r. kupili „realność” - nieruchomość na Wólce Pańskiej we Lwowie.

${ }^{51}$ Do tego listu dołączony jest list żony Bujaka do żony Zakrzewskiego - Sydonii: „Kochana Pani, serdecznie dziękuję za odezwanie się do mnie. Nie odpowiadam osobnym listem, bo mię pisanie dużo kosztuje, trochę ze względu na ból w ręce, a więcej na ogólne zmęczenie i wyczerpanie spowodowane ciagle trwająca gorączka. Niby to tutaj mi się poprawia, ale b[ardzo] powoli. Nasze plany na zimę sa jeszcze niejasne. Chcieliśmy jechać stąd wprost dalej na południe, ale mój stryj jest za tym, żebym na jesieni była w Warszawie dla kuracji, a ewentualnie potem drugi raz wyjechała. Może tak zrobimy, bo i Franek zapewne będzie musiał składać przysięgę i objąć urzędowanie, potem chyba będzie mógł się zwolnić. Zresztą czekamy jeszcze końca pobytu tutaj i rad tutejszego lekarza. Z dziećmi na szczęście nie znamy kłopotu, sa zdrowe i normalnie się rozwijaja. Dobrze się tu bawią na piasku. [...] Grado, jako miejsce odpoczynku, nie przedstawia wiele przyjemności, szczególniej, jak upały sa b[ardzo] męczące. [...] Bardzo mi będzie miło znów coś od Pani usłyszeć o Rodzinie Państwa, którą oboje serdecznie wspominamy. Łącze pozdrowienia dla obojga Państwa. Ewa B.” 
bardziej mi miła, choć w moje doli nic mi pomóc nie może ${ }^{52}$. Do spokoju, równowagi ogromnie mi jeszcze daleko. Nie odpisywałem $\mathrm{Ci}$, bo i zajęcia mi przeszkadzały (sprowadziłem z Warszawy dzieci i urządziłem mieszkanie), i chciałem Wam posłać na pamiątkę szczerze Wam życzliwej nieodżałowanej mojej żony fotografię. Gdybyście już mieli tę fotografię, to odeślijcie ją mojemu bratu ${ }^{53}$, a ja Wam poślę inną bardziej podobna, choć mniej korzystna.

Z dziećmi jest mi znacznie znośniej. Dzieci pięknie się rozwijaja i bardzo sa do mnie przywiązane. Na szczęście dla nich i dla mnie maja pełna poświęcenia opiekunkę w mojej siostrze stryjecznej ${ }^{54}$.

Zasyłam serdeczne pozdrowienia dla Pani Sydonii i szczery uścisk dla Ciebie.

Kraków, ul. Studencka 4.

Franek

8. ZNiO, rkps Ossol. 7343/II, k. 295-296

[Kraków?], 22 I 1913 r.

Kochany Staszku,

Dziękuję za kartkę bardzo uprzejmie, jak również i za zaproszenie. O Maszkienicach mówić nie mogę, bom i w Akademii nie mówił. Ulanowski ogłosił nie porozumiewawszy się ze mną, a ja nie wiedząc, nie przygotowałem.

Mogę mieć odczyt o rozwoju społeczno-gospodarczym Galicji pod rządami austriackimi (ogólny zarys do dni ostatnich) albo też mógłbym powiedzieć kilka uwag o emigracji zarobkowej, a mianowicie o jej skutkach, albo też o polskości Lwowa i widokach na przyszłość. Odpisz mi natychmiast, który odczyt chciałbyś, pierwszy mam gotowy, drugi w 3/4 tych, trzeci musiałbym dopiero opracować, bo mam tylko ideę.

Klubowi napiszę, że się zgadzam na odczyt i że Tobie wybór zaleciłem.

Przyjadę do Lwowa prawdopodobnie w piątek 31 I, mógłbym mieć odczyt w sobotę.

Całuję Cię

Franek

5213 IX 1909 r. zmarła żona Franciszka Bujaka - Ewa.

53 Jan Bujak (1880-1967), brat Franciszka, właściciel sklepu z aparatami fotograficznymi oraz Fabryki Przyrządów Mierniczych we Lwowie.

${ }^{54}$ Anna Bujak była kuzynką Franciszka, która po śmierci jego żony Ewy zajmowała się wychowaniem dzieci i prowadzeniem domu. W 1932 r., po uzyskaniu zezwolenia od papieża, Anna i Franciszek wzięli ślub. 
9. ZNiO, rkps Ossol. 7343/II, k. 301-302

Kochany Staszku!

[b.m.], 26 XII 1916 r.

$\mathrm{Z}$ całego serca dziękuje Ci za Twój list z wyrazami współczucia ${ }^{55}$. Naprawdę miło mi było otrzymać od Ciebie ten dowód przyjaźni i sympatii. W pierwszych dniach naturalnie takie listy raczej boleść powiększaja, ale potem stają się czemś rzewnem i kojącem.

Ogromnie mi żal tego najmilszego z moich dzieci, który się zarazem zapowiadał najlepiej na życie, o którego powodzeniu w życiu najwięcej marzyłem. W jego śmierci jakby część mnie samego zginęła, czuję to wyraźnie. Do tego i starszy chłopiec ${ }^{56}$ nie celuje zdrowiem, obecnie polecili go lekarze wysłać do Zakopanego. Niewiara, odpływ siły życiowej zalewa mnie zupełnie. Myślę tylko wykonać to, do czego się zobowiązałem. Czy się dźwignę z tego stanu likwidacji?

Wielce Szanownej Pani osobno serdecznie dziękuję za Jej łaskawe słowa zwrócone do mnie w tem nieszczęściu. Zarazem załączam najserdeczniejsze życzenia na nadchodzący Nowy Rok dla Obojga Państwa i dla Dzieci.

Szczerze oddany

F. Bujak

10. ZNiO, rkps Ossol. 7343/II, k. 303-304

[b.m.], 25 XII 1918 r.

Kochany Staszku!

Doszło do mojej wiadomości, że piszesz jakiś referat historyczny o wschodniej Galicji ${ }^{57}$ (zdaje się w porozumieniu z Romerem ${ }^{58}$ ). Jako zajmujący się sprawami zaboru austriackiego w Biurze Kongresowym ${ }^{59}$

5524 XI 1916 r. zmarł dziewięcioletni syn Franciszka Bujaka - Stanisław.

${ }^{56}$ Syn Jakub (1905-1945), dr nauk technicznych Politechniki Lwowskiej; miłośnik gór, taternik i alpinista.

57 S. Zakrzewski, E. Romer, S. Pawłowski, W obronie Galicyi Wschodniej, Lwów 1919.

${ }^{58}$ Eugeniusz Romer (1871-1954), geograf i kartograf, autor prac geograficzno-historycznych. Studiował geografię i historię na UJ, w 1894 r. obronił doktorat na Uniwersytecie Lwowskim, w 1899 r. uzyskał veniam legendi, od 1911 r. profesor zwyczajny UL. Był przyjacielem F. Bujaka.

${ }_{59}$ Biuro Prac Kongresowych powstało w listopadzie 1918 r. Jego zadaniem było przygotowanie materiałów dla Delegacji Polskiej na Konferencję Pokojową w Paryżu. 
proszę Cię bardzo o zawiadomienie mnie, w jakim stanie znajduje się Twoja praca i w jakim kierunku idzie, i kiedy będzie gotowa.

Byłbym Ci niezmiernie wdzięczny, gdybyś doniósł mi, co i w jakim kierunku pisze dr Modelski ${ }^{60}$ i na kiedy będzie gotów. Słyszałem, że coś o Spiszu i Słowaczyźnie wschodniej. Nie piszę do niego, bo nie znam jego adresu.

Gdybyś miał jakiś pomysł, jaką́s inicjatywę dla Biura Kongresowego, bardzo gorąco Cię proszę, abyś łaskawie mi to zakomunikował tak odnośnie do siebie, jak i do innych. Projekty urządzenia stosunków na wsch[odniej] Galicji (autonomia dla Ukraińców, Starorusinów i Żydów) są bardzo pożądane.

Zapewne na Wólce były ciężkie dni w czasie listopada. Czy mieszkacie tam jeszcze?

Piękne ukłony dla Pani i córek, uściski serdecznie dla Ciebie

Twój Franek

\section{ZNiO, rkps Ossol. 7343/II, k. 305-308}

[Warszawa?], 16 I $1920 \mathrm{r}$.

Mój Drogi!

Trochę może za późno, o ile chodzi o naszą rozmowę, ale zapewne jeszcze nie za późno, o ile chodzi o rzecz, odpisuję $\mathrm{Ci}$ w materii katedry $^{61}$. Otóż decyduję się przyjąć katedrę historii gospodarczej i społecznej na Wyd[ziale] Filoz[oficznym] Uniwersytetu Lwowskiego. Chodzi mi o czas i spokój do pracy, liczę, że pod tym względem Wydział Filoz[oficzny] będzie miał życzliwe usposobienie względem mnie i wyrozumiałość. Z góry więc postanawiam sobie nie dać się wciagnać do żadnej pracy zbiorowej, a już zgoła do żadnej politycznej; odmówić sobie także postanowiłem zarobków ubocznych (wykładów zastępczych itp.).

Franciszek Bujak pełnił funkcje przedstawiciela Biura do spraw Galicji i brał udział w konferencji jako ekspert w sprawach ekonomicznych.

${ }^{60}$ Teofil Emil Modelski (1881-1967), mediewista, studiował na Uniwersytecie Lwowskim, w 1909 r. obronił doktorat, w 1917 r. otrzymał habilitację z zakresu historii austriackiej i historii średniowiecza powszechnego. Od 1924 r. profesor zwyczajny Uniwersytetu Stefana Batorego w Wilnie, w 1930 r. został kierownikiem Katedry Historii Średniowiecznej na UJK we Lwowie.

${ }^{61}$ Stanisław Zakrzewski, pełniący funkcję dziekana Wydziału Filozoficznego Uniwersytetu Lwowskiego, zaproponował Bujakowi objęcie Katedry Historii Społecznej i Gospodarczej. Bujak propozycję przyjał. 
Byłbym rad gdybyście mi dali urlop na pierwsze półrocze po nominacji, która oby jak najprędzej nastapiła. Co do seminarium to chciałbym uniknać kłopotów organizowania go, chętnie bym się zgodził na przyjęcie mnie do semin[arium] hist[orii] powszech[nej] lub semin[arium] hist[orii] polskiej z osobna dotacja - ale bez kupowania i tworzenia osobnej biblioteki. Jeżeliby Wam to nie dogadzało, to gotów jestem zrzec się dotacji i płacy za prowadzenie ćwiczeń, zastrzegając sobie prawo odbywania ćwiczeń w obrębie moich godzin obowiązkowych.

Chciałbym w prawach mieszkaniowych liczyć na 1) pomoc urzędowa co do zdobycia mieszkania, które chciałbym mieć dostatecznie wygodne, dalej 2) na zwrot rzeczywistych kosztów przesiedlenia się z Warszawy do Lwowa, wreszcie 3) na jakieś uzupełnienie moich obecnych dochodów uniwersyteckich.

Deklaracje o nierobieniu starań o inne stanowisko bez wiedzy Wydziału napiszę chętnie (nie wyłączając powołania do rządu).

Z Ptaśnikiem, który mnie odwiedził, mówiłem o tej sprawie otwarcie. Serdecznie pozdrawiam i uściski załączam.

F. Bujak

PS. Nie wiem, czy robię dobrze (rzadko można być pewnym z takim jak moje usposobieniem), ale uważam, żem ten krok powinien zrobić, chcę bowiem zrobić wszystko, aby mimo małej mej wydajności w pracy, choć co ważniejsze zaczęte roboty do końca doprowadzić. Innego sposobu nie widzę; jeżeli i ten jest chybiony, to darmo, szkoda tylko kłopotów i straty w dochodach. Twój FB

\section{ZNiO, rkps Ossol. 7343/II, k. 309}

[b.m.], 20 III $1920 \mathrm{r}$.

\section{Kochany Staszku!}

W sprawie gmachu posejmowego dwa razy rozmawiałem z posłem Raczkowskim ${ }^{62}$, zapewniał mnie, że pisał i że pewny jest pomyślnego rezultatu $^{63}$. Na wszelki wypadek daj mi znać, gdyby pożądanego skutku nie było. Skład mojej rodziny 5 osób - córka 16 lat, syn 14 lat muszą

${ }^{62}$ Feliks Raczkowski (1876-?), poseł na Sejm II RP w latach 1919-1927.

${ }_{63} \mathrm{Już}$ w listopadzie 1918 r. członkowie Senatu Akademickiego Uniwersytetu Lwowskiego rozpoczęli starania o pozyskanie budynku Sejmu Galicyjskiego. Przekazano je UL w lutym 1920 r. 
mieć osobne pokoje, gospodyni moja także, dla mnie potrzebna pracownia i sypialnia, nadto dla wszystkich jadalny pokój, razem 6 pokoi. Nie chciałbym w mieście starem, ale gdzieś w dzielnicach nowszych, ile możności, w pobliżu tramwaju w okolicach Cytadeli lub Politechniki.

Serdeczne pozdrowienia

Franek

13. ZNiO, rkps Ossol. 7343/II, k. 311-312

[Warszawa?], 27 IV $1921 \mathrm{r}$.

Kochany Staszku!

Dziękuję Ci za kartkę z Poznania, ciekawym skąd źródło tej nieufności władzy kościelnej do Ciebie jako badacza?

Byłem w tych dniach we Lwowie, oglądałem z prof. Bulanda ${ }^{64}$ Twój lokal, wniosłem odpowiednie pismo do dziekana, wczoraj miał się ta sprawą (ze wglądu na wodociag) zajać Senat. Teraz od Ciebie zależy, kiedy postanowisz i będziesz mógł zrobić przeprowadzkę dawnego lokalu. Chciałbym jak najmniej czasu stracić i przygotowywać się do przeprowadzki.

Żałuję, żeś nie wstapił do nas przed wyjazdem do Poznania. Pokłoń się Rutkowskiemu ${ }^{65} \mathrm{i}$ innym moim znajomym. Jeżeli pojedziesz z Poznania do Lwowa przez Warszawę nie zapomnij wstapić. Ciekawym Twoich spostrzeżeń o Poznaniu i tamtejszych stosunkach.

Serdecznie Cię ściskam

Franek

${ }^{64}$ Edmund Bulanda (1882-1951), archeolog klasyczny, w 1916 r. powołany na Katedrę Archeologii Uniwersytetu Lwowskiego jako profesor nadzwyczajny, w 1920 r. został profesorem zwyczajnym.

${ }^{65}$ Jan Rutkowski (1886-1949), badacz dziejów gospodarczych, studiował historię pod kierunkiem Ludwika Finkla i S. Zakrzewskiego na Uniwersytecie Lwowskim, od 1919 r. profesor nadzwyczajny i kierownik Katedry Historii Gospodarczej na Uniwersytecie Poznańskim, profesor zwyczajny od 1920 r. W latach 1931-1939 wydawał wspólnie z Bujakiem „Roczniki Dziejów Społecznych i Gospodarczych”. 


\section{ZNiO, rkps Ossol. 7343/II, k. 313-315}

[Rabka-Zdrój], 26 VII 1921 r.

\section{Drogi Staszku!}

Z Warszawy wyjechałem nagle, wezwany telegraficznie do córki66; tak, że [nie] miałem czasu nawet pożegnać się z Tobą. Gdym zajrzał do Warszawy już Ciebie nie było. Mam nadzieje, że jesteś już z powrotem we Lwowie, albo gdzieś w pobliżu i dlatego ocknąwszy się trochę, piszę. Chciałbym się mianowicie dowiedzieć, jak stoi sprawa przeniesienia Twojego seminarium do nowego lokalu i opowiedzieć Ci jak moje sprawy mieszkaniowe się przedstawiaja.

Co do mojego domu przy ul. Sadownickiej, to zdaje się uzyskałem tylko w II-giej instancji zniesienie wyroku I-szej instancji i możność toczenia procesu na nowo - bodaj przez rok, ale pozytywnie jeszcze nie wiem co się stało, bo wyrok ma być wydany na piśmie. Co do mieszkania zarekwirowanego to nie wiem, czy jest ono już po załatwieniu rekursów, pomyślnych dla mnie. Swoją droga obecnie jest taka sytuacja, że moge go wziąć dla ewentualnej zmiany tylko. Moja córka nie chodzi już prawie i mieszkanie na II-gim piętrze bez windy jest niemożliwe dla niej, bo jednak dla spaceru musi codziennie chyba być wywożona na ulicę czy do ogrodu.

Jak widzisz moje położenie pogorszyło się od zeszłego roku ogromnie. Jeżeli nie dostanę mieszkania w dawnym rektoracie to nie wiem, czy będę we Lwowie mieszkał w przyszłym roku szkolnym, choć mam zamiar przyjechać do Lwowa we wrześniu z córką dla próbowania leczenia u Rychnowskiego ${ }^{67}$, decydując się mieszkać z nią w hotelu. Zreszta pędzę tu w Rabce czas trochę na pracy, trochę na zabawianiu córki.

Co u Ciebie słychać? Jakie masz wieści z podróży do Włocławka? Czy rodzina Twoja wyjechała na wieś? Czy przypadkiem nie wiadomo $\mathrm{Ci}$, czy by mi kto nie mógł odstapić w bardzo bliskim sasiedztwie z Rychnowskim (Chorążczyzna) pokoju zacisznego z 2 łóżkami lub łóżkiem i sofą do spania (bez pościeli) na wrzesień. Jak lekarz powiada nawet przewożenie jej dalsze jest dla jej zdrowia niekorzystne.

Serdecznie Cię ściskam

Franek

${ }^{66}$ Córka Ewa chorowała na białaczkę, zmarła w 1927 r., w wieku 23 lat.

${ }^{67}$ Franciszek Rychnowski (1850-1929), inżynier, konstruktor, wynalazca, ukończył studia na Wydziale Mechanicznym Politechniki w Wiedniu, w 1875 r. przeniósł się do Lwowa, w 1891 r. ogłosił odkrycie nieznanej materii - „eteroidu”, która przyrównywał do energii życiowej mogącej m.in. leczyć choroby nowotworowe. Mieszkał we Lwowie przy ul. Chorążczyzny 15. 
15. ZNiO, rkps Ossol. 7343/II, k. 317

[Kraków], 22 III 1922 r.

Kochany Staszku,

Choroba syna zatrzymuje mnie jak wiesz w Krakowie. Dotąd jeszcze gorączkuje, nie moge go opuścić przed powrotem do normalnej temperatury. Mam nadzieję, że uda mi się wrócić przed $1 \mathrm{X}$, ale na wszelki wypadek proszę Cię, abyś zawiadomił o mojej sytuacji dziekanat i poprosił go o krótkoterminowy urlop dla mnie.

Byłbym także wdzięczny za informacje, co słychać w Uniwersytecie, a specjalnie w sprawach bliżej mnie dotyczacych.

U mnie właściwie nic nowego, siedzę w sanatorium i mało się z ludźmi komunikuję, czasem tyko do Biblioteki Jag[iellońskiej] zaglądam.

Serdeczne pozdrowienia i uściski

F. Bujak

Adres: Kraków, ul. Siemiradzkiego 1

PS. Czy Szelagowski powrócił i czy tego służącego z Maszkienic sobie sprowadził?

\section{ZNiO, rkps Ossol. 7343/II, k. 319-321}

[Lwów?], 4 V 1925 r.

\section{Drogi Staszku,}

Zdaje mi się, że jest ryzykowne wygłaszanie takich odezw w liczbie 600 - czy więcej, z których wynika, że uważamy za naturalne i obowiązujące nadesłanie referatu przez adresata ${ }^{68}$. Wszak jest podobno 60 referatów. Gdyby tak napłynęło jeszcze z $60-80$ wskutek tej odezwy, to bylibyśmy w kłopocie choćby z czytaniem rękopisów i kwalifikowaniem ich.

Podpisałem na razie 300 mniej więcej - co do reszty chciałbym Twego zdania o mojej opinii, moich wątpliwościach. Może wysłać w innej formie odezwę?

Uściski

F. Bujak

${ }^{68}$ Zjazd Historyków Polskich w Poznaniu odbył się 6-8 XII 1925 r. 
W Statucie Tow[arzystwa] Miłośników ${ }^{69}$ zauważyłem, że w $§ 11$ członkowie otrzymuja „Kwartalnik Hist[oryczny]” za darmo, gdy nie wiadomo, czy Tow[arzystwo] będzie się stosowało co do wysokości składek do norm Tow[arzystwa] Histor[ycznego]. W § 27 jest mowa o oddawaniu do kasy Tow[arzystwa] Hist[orycznego] 50\% składek, czy one będa równe świadczeniom innych członków Tow[arzystwa] Hist[orycznego] i czy one wystarczą na pokrycie kosztów „Kwartalnika” w tym stosunku, jak się je będzie policzało innym członkom?

Tyle na razie, F. Bujak

Wprowadzenie zupełnej wzajemności co do wydawnictw - może budzić także wątpliwości.

17. ZNiO, rkps Ossol. 7343/II, k. 323-324

[Lwów?], 12 XI 1925 r.

Kochany Staszku,

Żałuję bardzo, że ustnie Cię nie prosiłem 1) o ocenę pracy Inglota ${ }^{70}$, który radby $\mathrm{w}$ przyszłym tygodniu zdawać małe rygorozum, 2) o to czybyś nie zechciał ustapić prof. Starzyńskiemu ${ }^{71}$ sali, w której obecnie wykładasz. On w niej wykładał, korzystając z Twojej nieobecności. Wykłada dla kursu o Polsce współczesnej i miał już jakieś nieprzyjemności z tą salą wykładowa. Gdzie mógłbyś wykładać indziej niestety nie umiem $\mathrm{Ci}$ poradzić.

Zwracam się zaś do Ciebie na jego i dziekana życzenie. Prof. Starzyński grozi, że inaczej wykład zawiesi, a jest to wykład dla kursu esencjonalny (konstytucja polska).

${ }^{69}$ Towarzystwo Miłośników Historii w Warszawie zostało założone w $1906 \mathrm{r}$., w $1925 \mathrm{r}$. funkcjonowało jako oddział warszawski Polskiego Towarzystwa Historycznego.

70 Stefan Inglot (1902-1994), w 1926 r. obronił pod kierunkiem F. Bujaka doktorat pt. „Stosunki społeczno-gospodarcze ludności w dobrach biskupstwa włocławskiego w pierwszej połowie XVI w.”, recenzentem był S. Zakrzewski. W 1932 r. uzyskał habilitację na UJK na podstawie pracy pt. „Koloni w średniowiecznej Alzacji” (druk: PAU w Krakowie 1930), w 1939 r. prof. tytularny UJK. Jako student był asystentem prof. Bujaka w Katedrze Historii Społecznej i Gospodarczej UJK w latach 1922-1924.

${ }^{71}$ Stanisław Starzyński (1853-1935), prawnik i polityk, profesor prawa politycznego na Uniwersytecie Lwowskim, od 1892 r. profesor zwyczajny. Autor wielu prac $\mathrm{z}$ zakresu historii prawa konstytucyjnego. 
Bądź łaskaw rozważyć w Twym sercu tę sprawę i łaskawie dla dobra sprawy rozstrzygnaćc.

Ściskam Cię

Twój Franek

18. ZNiO, rkps Ossol. 7343/II, k. 325

[Lwów], 30 XII 1927 r.

Kochany Stasiu,

Jakoś nie udało mi się ani telefonem, ani własną ręką i głosem dosięgnąc Cię przez dwa ostatnie dni, piszę więc z prośba, abyście łaskawi Państwo wybaczyli nam, że nie możemy razem z Wami sylwestrować. Poprzedniego wieczoru przed Twoim telefonem zaprosili nas (tj. mnie) Jankowie $^{72}$ na taką z nazwy, ale nie tak wesołą jak u Was ucztę sylwestrowa. Hanusia ${ }^{73}$ jeszcze wtedy nie wiedziała o tym, więc nie mogła od razu odmówić się od Twego zaproszenia. Przepraszam Ciebie i Panią Sydonię i za zawód, i za opóźnienie odpowiedzi. Najlepsze życzenia na Nowy Rok całej Rodzinie życzymy wszyscy.

F. Bujak

19. ZNiO, rkps Ossol. 7343/II, k. 331

[Lwów], 22 II 1929 r.

Kochany Staszku,

Oznajmiono mi, żeś do mnie telefonował przed $1 \frac{1}{2} 2$ godz. w południe. Przypuszczam, że chodziło o sprawy Towarzystwa Hist[orycznego] ${ }^{74}$.

$\mathrm{O}$ ile chodzi o posiedzenie do $10 \mathrm{III}$ w niedzielę i $11 \mathrm{III}$ ewentualnie posiedzenie Zarządu Głównego w Krakowie jest dla mnie odpowiednie i na ten termin moja zgoda. Jeżeli chodzi także o inne sprawy, to przyjdę w sobotę między $12-1$ do Twojego seminarium lub gdzie i kiedy sobie będziesz życzył.

Uściski łączę

Franek

${ }^{72}$ Chodzi o brata Franciszka Bujaka - Jana wraz z rodzina.

${ }^{73}$ Chodzi o Annę Bujak, zob. przyp. 54.

${ }^{74}$ Stanisław Zakrzewski był w 1929 r. prezesem Polskiego Towarzystwa Historycznego. 
20. ZNiO, rkps Ossol. 7343/II, k. 333

Lwów, 6 IV 1929 r.

J[aśnie] W[ielmoż]ny Pan

Prof. Dr St[anisław] Zakrzewski

we Lwowie

Wielce Szanowny Panie Kolego!

Proszę Pana Kolegę, jako seniora historyków naszego fakultetu, o urządzenie posiedzenia Komisji historycznej, ponieważ chciałbym na niej poruszyć sprawę wymagań egzaminacyjnych.

Przesyłam uprzejmie pozdrowienia i wyrazy szacunku

F. Bujak

21. ZNiO, rkps Ossol. 7343/II, k. 335-336

Lwów, 19 IV 1929 r.

J[aśnie] W[ielmoż]ny Pan

Prof. Dr St[anisław] Zakrzewski

we Lwowie

Wielce Szanowny Panie Kolego!

Żałuje, że na dzisiejszej konferencji nie mogę być obecny, stan zdrowia bowiem zatrzymuje mnie w łóżku. Żałuję tym bardziej, że sprawa, o która mi chodzi zyskałaby tylko na ustnym omówieniu i może uchroniłaby mnie od możliwych nieporozumień.

W ostatnich dniach II trymestru spotkałem się ze skargami, że stawiam zbyt wysokie wymagania, że rzadko pierwsza praca u mnie jest uznawana za kandydacką i to dopiero po przeróbkach i uzupełnieniach, i że z reguły dopiero druga praca, której wykonanie zabiera co najmniej drugi rok czasu, bywa przeze mnie uznana za kandydacka. Wskazano mi równocześnie, że w Seminarium prof. Chylińskiego ${ }^{75}$ pracę kandydacką wykonuje się z reguły $\mathrm{w}$ przeciagu kilku miesięcy, bo jest ona

${ }^{75}$ Konstanty Chyliński (1881-1939), kształcił się w Petersburgu, gdzie na tamtejszym uniwersytecie otrzymał dyplom I stopnia z nauk historycznych ze szczególnym uwzględnieniem historii starożytnej (co było równoznaczne z habilitacja), od $1921 \mathrm{r}$. profesor zwyczajny historii starożytnej UJK. Prowadzone przez niego seminarium cieszyło się ogromną popularnością wśród studentów studium historycznego na UJK. 
zwykle oparta na literaturze i to bardzo ograniczonej, a nie na źródłach. Twierdzenia tego nie mogę sprawdzić, ponieważ ani razu nie byłem referentem drugim rozprawy kandydackiej wykonanej u prof. Chylińskiego. Mam jednak nadzieję, że studenci, którzy się do mnie z tym zwracali, nie chcieli mię w błąd wprowadzić.

Nie chodzi mi tutaj o żadne kwestie osobiste, ponieważ mimo surowych wymogów mam dotąd w Seminarium tylu uczniów, ilu ich mogę pomieścić i osobiście kierować ich pracami. Uważam jednak, że powstaje wskutek tego nierównomierność w traktowaniu kandydatów, jedni mianowicie uzyskuja małym nakładem pracy patenty nauczycielskie, inni bez porównania większym, a więc zapewne i później. Pomijam tutaj kwestie lepszego lub gorszego w rzeczywistości przygotowania do zawodu nauczycielskiego.

Według protokołu Komisji egzaminacyjnej od 15 marca 1928 do końca marca 1929 została przyjęta względnie zgłoszona następująca ilość prac egzaminacyjnych $\mathrm{z}$ historii:

$\begin{array}{lcccccc} & \text { Bujak } & \text { Chyliński } & \text { Łempicki }^{76} & \text { Ptaśnik } & \text { Szelag[owski] } & \text { Zakrzewski } \\ \text { Polacy } & 5 & 7 & - & 5 & - & 8 \\ \text { Rusini } & - & 13 & 1 & 1 & - & 6 \\ \text { Żydzi } & 2 & 4 & - & 4 & 2 & 2 \\ \text { Nieoznaczeni } & - & 3 & 1 & - & - & 1 \\ \text { Razem } & 7 & 27 & 2 & 10 & 2 & 17=65\end{array}$

Jeżeli niewiadomych rozdzielimy proporcjonalnie pomiędzy trzy narodowości, to otrzymamy, że na 65 prac zgłosili Polacy 28 (43\%), Rusini 22 (34\%), Żydzi 14 (22,5\%).

Zasadniczo nie można mieć nic przeciw zgłaszaniu się do egzaminu kandydatów wszystkich trzech narodowości, jednak byłoby niesprawiedliwym, gdyby większość kandydatów obcych narodowości korzystała z przywileju mniejszych wymogów egzaminacyjnych. Wobec tego uważam za konieczne wyrównanie tych wymagań i w tym celu jest niezbędne porozumienie się egzaminatorów. Ponieważ, o ile wiem, wymagania stawiane pracom są mniej więcej jednakowe u prof. Zakrzewskiego, Ptaśnika, Szelagowskiego i u mnie, wydałoby się słuszne dostosowanie się pod tym względem prof. Ch[ylińskiego] do większości.

${ }^{76}$ Stanisław Łempicki (1886-1947), historyk oświaty i szkolnictwa, ukończył Wydział Filozoficzny Uniwersytetu Lwowskiego, od 1924 r. profesor nadzwyczajny UJK i kierownik Katedry Historii Oświaty i Szkolnictwa, od 1933 r. profesor zwyczajny. 
Bardzo pragnę, ażeby ten mój głos nie stał się przyczyną obrazy dla p. Kolegi Ch[ylińskiego], proszę tedy Pana Kolegę, aby był łaskaw mój głos przedstawić w sposób, jak najmniej dajacy do tego powodu.

Łączę wyrazy szacunku. Szczerze oddany

F. Bujak

22. ZNiO, rkps Ossol. 7343/II, k. 337-338

Lwów, 22 V 1929 r.

Kochany Staszku,

Romer zajął mi czas do godz. 6.50 min[imum]. Próbowałem telefonować potem, ale bezskutecznie, zreszta miałem seminarium.

Co do udziału w planowanym przez Ciebie podręczniku, to gotów jestem do niego, ale mam czas tak zajęty, że na pisanie do niego nie mogę liczyć wcześniej, jak w przyszłym roku. Specjalnie do dostarczenia rękopisu Igo zeszytu w październiku br. nie mogę się zobowiązać: 1) z braku na to czasu, 2) ponieważ wpierw muszę się wywiązać ze zobowiązania do napisania analogicznego wstępu geograficznego do Hist[orii] Polskiej planowanej przez Konopczyńskiego ${ }^{77}$ w Kasie Mianowskiego. Od 2 lat zwlekam i odkładam termin!

Byłbym człowiekiem pogardy godnym gdybym teraz oddał się na usługi innej [...]; chyba to zdanie podzielisz.

Wstęp geograficzny do planowanego przez Ciebie podręcznika mogę napisać dopiero po ukazaniu się tamtego. Przypuszczam, że nie zechcesz czekać. Gdybyś jednak koniecznie życzył sobie mojego współpracownictwa co do tego, to musiałbyś tak plan ułożyć, aby geografia nie zaczynała całego dzieła.

Co do historii gospodarczej służę chętnie, bo nie mam u Konopczyńskiego zobowiąania.

Przepraszam Cię jeżeli Ci to co piszę robi różnicę, ale tak się rzeczy maja niestety.

Serdeczne uściski

Franek

77 Władysław Konopczyński (1880-1952), historyk dziejów nowożytnych, profesor zwyczajny Uniwersytetu Jagiellońskiego, w latach 1917-1948 kierownik Katedry Historii Polski Nowożytnej i Najnowszej. W 1925 r. Bujak zgodził się na przygotowanie rozdziału poświęconego kwestiom geograficznym do wielotomowej syntezy dziejów Polski pod redakcja Konopczyńskiego. Przez 10 lat (w 1935 r. rozwiąano z Bujakiem umowę) nie napisał zapowiadanego rozdziału. Nie tylko Bujak nie wywiązywał się ze swoich zobowiązań. Dzieło to nigdy nie powstało. 


\section{ZNiO, rkps Ossol. 7343/II, k. 339-340}

Lwów, 22 VI 1929 r.

J[aśnie] W[ielmoż]ny Pan Profesor

Dr Stanisław Zakrzewski

we Lwowie

Wielce Szanowny Panie Kolego,

Spostrzeżenia poczynione przy tegorocznym egzaminie magisterskim z metodologii historycznej skłaniają mnie do zwrócenia się do Pana Kolegi, jako do Przewodniczącego Komisji Historycznej, w sprawie określenia wymagań przy egzaminie magisterskim metodologii historycznej, a to celem ujednostajnienia tych wymagań oraz określenia planu wykładu zleconego pt. Wstep do nauki historii, który obecnie w potrójnej formie jest prowadzony.

Nie mogac na razie $\mathrm{z}$ braku czasu szczegółowo uzasadniać, pozwalam sobie niniejszym przedłożyć jako materiał do dyskusji na Komisji Historycznej następujące punkty.

Przy egzaminie magisterskim należy wymagać:

1) Znajomości metodologii historycznej według Handelsmana ${ }^{78}$, a pomocniczo według Langloisa ${ }^{79}$ i Seignobosa ${ }^{80}$ oraz Bauera ${ }^{81}$. Ze względu na historię nowożytną bardzo pożądane jest przestudiowanie G. Wolfa ${ }^{82}$, Einführung in das Studium der neueren Geschichte, 1920.

2) Umiejętności praktycznego posługiwania się bibliografią Finkla ${ }^{83}$ i bibliografią w „Kwartalniku Historycznym”.

${ }^{78}$ Marceli Handelsman (1882-1945), mediewista, badacz dziejów nowożytnych i najnowszych, studiował historię na Uniwersytecie w Berlinie, następnie profesor Uniwersytetu Warszawskiego (od 1919 r. profesor zwyczajny). Autor podręcznika Historyka. Zasady metodologii i teorii poznania historycznego, Zamość 1921 (wyd. 2 rozsz., Warszawa 1928).

${ }^{79}$ Charles-Victor Langlois (1863-1929), francuski historyk średniowiecza, profesor Sorbony. Autor, wspólnie z Ch. Seignobosem, podręcznika Wstęp do badań historycznych (tłum. W. Górkowa, przedm. S. Zakrzewski, Lwów 1912).

${ }^{80}$ Charles Seignobos (1854-1942), historyk Francji, zwłaszcza okresu III Republiki, kształcił się w Niemczech, w 1881 r. obronił pracę doktorska, następnie mianowany na stanowisko profesora w Sorbonie. Autor, wspólnie z Ch. Langloisem, podręcznika Wstep do badań historycznych (zob. wyżej).

${ }^{81}$ Wilhelm Bauer (1877-1953), austriacki historyk dziejów nowożytnych i najnowszych, profesor Uniwersytetu Wiedeńskiego. W 1921 r. opublikował podręcznik Einführung in das Studium der Geschichte.

${ }^{82}$ Gustav Wolf (1865-1940), niemiecki historyk i profesor historii nowożytnej, wykładowca na Uniwersytecie we Freiburgu.

${ }^{83}$ Ludwik Finkel (1858-1930), badacz dziejów nowożytnych, w latach 1899-1917 profesor zwyczajny Uniwersytetu Lwowskiego, kierownik Katedry Historii Austrii. 
3) Poprawnego tłumaczenia nietrudnego łacińskiego tekstu źródłowego.

4) Znajomości kalendarza średniowiecznego (rozwiązywanie dat).

5) Wiadomości ogólnych z dziedziny nauk pomocniczych.

6) Znajomości historiografii polskiej.

7) Przestudiowania przynajmniej dwóch z cytowanych przez Handelsmana w części „Krytyka i hermeneutyka” ${ }^{44}$ rozpraw historycznych polskich.

Czy paleografia ma być wymagana jest dla mnie na razie wątpliwe. Pożądane być powinno wykazanie się lektura prywatna, na którą z polskich historyków zalecają się prace:

T. Wojciechowskiego ${ }^{85}$, K. Potkańskiego ${ }^{86}$, St. Zakrzewskiego, J. Ptaśnika, Wł. Semkowicza ${ }^{87}$, K. Tymienieckiego ${ }^{88}$, W. Sobieskiego, W. Konopczyńskiego, S. Askenazego ${ }^{89}$, W. Tokarza, M. Handelsmana.

Pożądane także być powinno przestudiowanie praktycznych wskazówek do pracy naukowej, które można znaleźć w publikacjach:

Studium historyczne na Uniwersytecie, Warszawa 1926.

K. Sochaniewicz ${ }^{90}$, Nauka historii ${ }^{91}$.

W latach 1891-1906 opublikował wspólnie z Henrykiem Sawczyńskim trzy tomy Bibliografii historii polskiej.

${ }^{84}$ Zob. w: M. Handelsman, Historyka..., s. 96-175 (wyd. 2, s. 129-201).

85 Tadeusz Wojciechowski (1838-1919), historyk mediewista, w 1883 r. otrzymal stanowisko profesora nadzwyczajnego i kierownika Katedry Historii Polski na Uniwersytecie Lwowskim.

${ }^{86}$ Karol Potkański (1861-1907), badacz dziejów średniowiecza Polski, od 1906 r. profesor zwyczajny Uniwersytetu Jagiellońskiego. Prowadził badania nad historia społeczno-gospodarcza.

87 Władysław Semkowicz (1878-1949), historyk mediewista, znawca nauk pomocniczych historii, w latach 1916-1939 kierował Katedra Nauk Pomocniczych Historii i Historii Średniowiecznej na Uniwersytecie Jagiellońskim (prof. zw. od 1919 r.).

${ }^{88}$ Kazimierz Tymieniecki (1887-1968), historyk mediewista, studiował historię na Uniwersytecie Jagiellońskim, w 1919 r. został profesorem nadzwyczajnym, a następnie w 1921 r. profesorem zwyczajnym Uniwersytetu Poznańskiego, kierował Katedra Historii Średniowiecznej.

89 Szymon Askenazy (1865-1935), historyk dziejów nowożytnych, studiował w Getyndze, tam uzyskał doktorat, w 1902 r. otrzymał tytuł profesora nadzwyczajnego historii nowożytnej na Uniwersytecie Lwowskim, w 1907 r. profesor zwyczajny i kierownik Katedry Historii Nowożytnej ze szczególnym uwzględnieniem dziejów Polski. W 1919 r. zrezygnował z pracy w UL.

${ }^{90}$ Kazimierz Sochaniewicz (1892-1930), w latach 1910/1911-1913/1914 uczęszczał na Wydział Filozoficzny Uniwersytetu Lwowskiego, w 1917 r. uzyskał doktorat filozofii na podstawie pracy napisanej pod kierunkiem S. Zakrzewskiego. Pracowal jako nauczyciel w lwowskich gimnazjach. W 1929 r. powołany na stanowisko archiwariusza w Archiwum Miasta Torunia.

${ }^{91}$ K. Sochaniewicz, Nauka historii. Wskazówki do samokształcenia, Lwów 1928. 
A. Meister ${ }^{92}$, Richtlinien für das Studium der Geschichte ${ }^{93}$.

Ustalenie wymogów przy egzaminie z metodologii historycznej przez Komisję historyczną Fakultetu i ogłoszenie ich na początku roku szkolnego 1929/[19]30 będzie bardzo ważną wskazówką dla młodzieży, ułatwi jej przygotowanie się do tego egzaminu, oszczędzi jej czasu, a Seminaria uzyskaja przygotowanych do pracy uczniów.

F. Bujak

24. ZNiO, rkps Ossol. 7343/II, k. 341

Lwów, 20 XI 1930 r.

Kochany Staszku,

Mam nadzieję, że jutro skończę tzw. Bilans wydawniczy ${ }^{94}$. W sobotę mógłby pójść na maszynę do składania. We wtorek mógłbym zrobić korektę, a na piątek mogłyby być gotowe odbitki, a więc zdążyłyby wyjść na zjazd. Może być ta rozprawa pomieszczona w pierwszym zeszycie „Kwartalnika” za 1931. Będzie tego około 11/2 arkusza. Czy zgadzasz się na to? Czy wystarczy Ci korekta do aprobaty?

Ja się zaziębiłem istotnie we wtorek. Dziś siedzę w domu kaszlę i gryzmolę. Ściskam Cię i zdrowia życzę.

Franek

\section{ZNiO, rkps Ossol. 7343/II, k. 343-344}

Lwów, 25 II $1931 \mathrm{r}$.

Szanowny Panie Prezesie i Kochany Kolego,

Ponieważ nie mogę być w Warszawie w czasie projektowanego przez Pana Prezesa posiedzenia Zarządu [Polskiego Towarzystwa Historycznego] pozwalam sobie zakomunikować, że co do reprezentacji polskiej w organizacji Zjazdu Międzynarodowego ${ }^{95}$ życzyłbym sobie możliwie

${ }^{92}$ Aloys Meister (1866-1925), niemiecki historyk mediewista, specjalizował się w historii Kościoła, profesor zwyczajny na Uniwersytecie w Münster.

${ }^{93}$ A. Meister, Richtlinien für das Studium der Geschichte des Mittelalters und der Neuzeit, Münster 1916.

94 Bilans wydawniczy historii polskiej za ostatnie lat 30 (1900-1930), Lwów 1930.

${ }_{95}$ VII Międzynarodowy Kongres Nauk Historycznych odbył się w Warszawie 21-28 VIII $1933 \mathrm{r}$. 
poważnego i silnego wydziału i dlatego proponuję, aby i Kraków był tam reprezentowany przez kol[egę] W. Sobieskiego ze względu, że zjazd ma także Kraków odwiedzić, a więc trzeba, aby ktoś tym się zajął.

Co do podania do Ministerstwa o subwencję, to mam watpliwości i to poważne co do racjonalności wydania przewodnika franc[uskiego] po Polsce przez Pol[skie] Tow[arzystwo] Hist[oryczne]. Ci, którzy będa chcieli zwiedzić Polskę, będa posługiwali się najchętniej Baedekerem, który i Polskę uwzględnia. Przewodników po Polsce w języku francuskim wydano już kilka, nie wiem, ale zapewne jeden lub drugi jest do nabycia. Można by nawet kupić np. 200 egz. dla ofiarowania tym, którzy by chcieli podróżować. Przewodnik nowy, jeżeli firma Hachette chce wydać; to powinna wydać sama. Mam także wrażenie, sadząc po kosztach druków V Zjazdu Polskiego, że i koszta druków zjazdowych i księgi zjazdowej mogłyby być skromniej preliminowane, wszak to kryzys gospodarczy, którego końca nie należy się spodziewać prędko. Przewodnik po Warszawie mógłby być tylko w 2 językach i w 2 tysiacach egzemplarzy, a więc i ta pozycja dałaby się zmniejszyć. Zapewne, że zmniejszenie subwencji należy zasadniczo do Ministerstwa, ale ja jestem zdania, że byłoby lepiej wystapić ze skromniejszymi żądaniami, a w razie przekroczenia prosić o dodatkowy kredyt w czerwcu lub lipcu 1933. Trzeba się liczyć z ciężkimi czasami dla budżetu, a nie hołdować zasadzie prapolskiej: zastaw się a postaw się, w odniesieniu nie do nas samych, ale do państwa.

F. Bujak

\section{ZNiO, rkps Ossol. 7343/II, k. 346}

[Lwów], 1 X 1931 r.

Kochany Staszku,

Równocześnie pozwalam sobie przesłać pod Twoim adresem 5 egz. mojej rozprawki o kryzysie rolnym ${ }^{96}$ i proszę Cię, abyś je rozdał tym z Twoich klubowych kolegów, którzy się interesują sprawami agrarnymi.

Serdeczne uściski łączę

F. Bujak

${ }_{96}$ F. Bujak, Przyczynki do charakterystyki kryzysu rolnego. Referat wygtoszony dnia 8 marca 1931 r. na Walnym Zgromadzeniu Czesko-Stowackiej Akademii Rolniczej w Pradze, „Przegląd Współczesny” 1931 (lipiec-wrzesień), R. 10, t. 38, s. 21-32. 
27. ZNiO, rkps Ossol. 7343/II, k. 347

[Lwów], 12 III 1932 r.

Kochany Staszku!

Jutro jest o 12-tej w Ratuszu uroczystość na cześć Tow[arzystwa] Miłośników Historii Lwowa i Czołowskiego ${ }^{97}$. Ponieważ Ciebie nie było, podpisałem lakoniczne pismo w imieniu Pol[skiego] Tow[arzystwa] Hist[orycznego] z tego powodu i zapowiedziałem moją obecność. Sądzę, że i Ty powinieneś przyjść.

Zapewne $\mathrm{w}$ domu zastaniesz zaproszenie na rygorozum Walawendera $^{98}$ - o 11-stej w poniedziałek. A nie gorsz się tam bardzo, gdy się będzie sypał, bo z powodu zamierzonego wyjazdu mojego zmusiłem go do zdawania - bez przerobienia materiału w całości.

Ściskam Cię

F. Bujak

28. ZNiO, rkps Ossol. 7343/II, k. 349

Paryż, 6 IV 1932 r.

\section{Kochany Staszku!}

Dopiero wczoraj przeglądając ostatni zeszyt „Kwartalnika” razem ze Sobieskim, spostrzegłem, żeś napisał z racji mojego jubileuszu tak sympatyczne, ale niewątpliwie przesadzone słowa. Serdecznie Ci dziękuję za to, co jest obok wyrazu koleżeństwa i przyjaźni jeszcze ocena - jak powiadam grubo przesadzona - publicznej i obywatelskiej strony mojej

${ }^{97}$ Aleksander Czołowski (1865[1869]-1944), historyk wojskowości, wydawca źródeł do dziejów Lwowa. Studiował prawo i historię na Uniwersytecie Lwowskim, w 1890 r. uzyskał doktorat. W 1905 r. został dyrektorem Archiwum Miejskiego we Lwowie. W 1932 r. przypadał jubileusz Towarzystwa Miłośników Przeszłości Lwowa, którego pomysłodawca był Czołowski, w związku z tym połączono go z jubileuszem czterdziestolecia jego pracy archiwalnej, naukowej i kulturalnej.

98 Antoni Walawender (1903-1960), ukończył historię na UJK, pod kierunkiem Bujaka przygotował doktorat pt. Kronika klęsk elementarnych $w$ Polsce $i$ w krajach sqsiednich w latach 1450-1586 (t. 1: Zjawiska meteorologiczne i pomory, Lwów 1932; t. 2: Zniszczenia wojenne i pożary, Lwów 1935), który obronił w 1932 r. W latach 1928-1933 był asystentem w Katedrze Historii Społecznej i Gospodarczej. W 1934 r. zatrudniony w Archiwum Państwowym w Poznaniu. W latach 1931-1934 sekretarz redakcji „Roczników Dziejów Społecznych i Gospodarczych”. 
pracy i mojego życia. Przyznam się, że nie przyszło mi nigdy na myśl, aby się można dopatrywać we mnie podobieństwa do Staszica. Ale skoroś to uczynił, to również otwarcie wyznam, czuję się z tego dumny (ale nie aż do zawrotu głowy! $)^{99}$.

Sobieski wrócił z Rywiery ${ }^{100}$ nieosobliwie usposobiony, mieszkamy w Bibliotece Pol[skiej] ${ }^{101}$, więc się często widujemy. Ja pracuję nad nowym wydaniem pracy o mapach żeglarskich, obecnie w Bibliotece Tow[arzystwa] Geograficznego, które ma ładna biblioteczkę specjalną z 400000 tomów złożona. Gdyby tak Pol[skie] Tow[arzystwo] Hist[oryczne] kiedyś doszło do założenia specjalnej biblioteki historycznej! Ze względu, że w Polsce tyle jest bibliotek zasobnych w rzeczy hist[orii] pol[skiej] należałoby pomyśleć o historii powszechnej w takiej Bibli[otece] Pol[skiej] Tow[arzystwa] Hist[orycznego]. Co ty o tym myślisz?

Dziśs będzie miał wykład o Napoleonie w Prusach Wschodnich prof. Driault ${ }^{102}$. Jest to jeden z wykładów organizowanych przez Sobieskiego. Połączony jest z piękna wystawką map i rycin dotyczących tematu wykładu. Wystawkę robi Biblioteka Polska.

Czy Ci doręczono pracę Walawendera?

Załączam serdeczne pozdrowienia dla całej Twojej Rodziny i uściski dla Ciebie - oddany

Franek

${ }^{99} \mathrm{~S}$. Zakrzewski z okazji rocznicy 30-lecia pracy naukowej i 10-lecia pracy pedagogicznej F. Bujaka we Lwowie napisał krótki tekst, w którym stwierdził m.in.: „W postaci Jubilata jest coś, co przypomina mi niejednokrotnie Stanisława Staszica; nie myślę naturalnie o identyfikacji, lecz pewnej analogji. Zdolność i zainteresowanie do regestracji podstawowych, codziennych objawów życia społecznego; serdeczne i organiczne poczucie łączności ze środowiskiem, z którego obydwaj wyszli, przyczem Bujak pod tym względem, znacznie przewyższa Staszica”; S. Zakrzewski, Jubileusz Prof. Dr. Franciszka Bujaka, „Wiadomości Historyczne. Dodatek do »Kwartalnika Historycznego" 45, 1931, s. 155-156.

100 Chodzi o Riwierę Francuską zwaną też Lazurowym Wybrzeżem.

101 Biblioteka Polska w Paryżu powstała w 1838 r. W 1893 r. jej zbiory, fundusze i dom zostały przekazane Akademii Umiejętności. W okresie międzywojennym organizowano tam m.in. odczyty polskich i francuskich uczonych oraz wystawy dotyczące głównie spraw polskich.

102 Jean-Édouard Driault (1864-1947), francuski historyk, badacz dziejów starożytnych oraz XIX w. W 1912 r. powołał „Revue des études napoléoniennes”. 
29. ZNiO, rkps Ossol. 7343/II, k. 351

[Lwów], 8 X 1932 r.

Kochany Staszku!

Od 3 dni telefonuję i zachodzę do Twojego zakładu, aby się z Tobą porozumieć, ale nadaremnie, muszę więc użyć tego dawnego sposobu co Ty tj. pisania.

Najpierw chciałbym Cię gorąco i stanowczo namówić, abyś zgłosił referat o Chrobrym na Zjazd Międzynarodowy, ja bym zaś wziął inny temat. Chrobry jest doskonałym tematem na Zjazd Międzynarodowy.

Następnie chciałbym Cię zapytać, czy nie mógłbyśs zacząć roku w Oddziale P[olskiego] Tow[arzystwa] Hist[orycznego] od mojego odczytu „O Wjatyczach”103, bo w Warszawie nie było żadnej poważnej dyskusji prócz głosu prof. Arnolda ${ }^{104}$, a bardzo radbym, aby słyszeć zdania Czekanowskiego ${ }^{105}$, Taszyckiego ${ }^{106}$, Sulimirskiego ${ }^{107}$ i ewentualnie Fischera ${ }^{108}$ oraz innych lingwistów.

Ściskam Cię serdecznie

Franek

${ }^{103}$ F. Bujak, Skad przyszli Wjatycze na Ruś? Komunikat wygłoszony dnia $3 X$ 1932 r., „Sprawozdania z posiedzeń Wydziału II Nauk Społecznych, Historycznych i Filologicznych Towarzystwa Naukowego Warszawskiego" 1932, s. 141-143.

104 Stanisław Arnold (1895-1973), historyk mediewista, profesor nadzwyczajny Uniwersytetu Warszawskiego (od 1929 r.), w 1938 r. otrzymał tytuł profesora zwyczajnego. Od 1931 r. kierował pracami nad Stownikiem geograficznym państwa polskiego.

105 Jan Czekanowski (1882-1965), antropolog, etnolog, slawista, od 1913 r. profesor zwyczajny na Uniwersytecie Lwowskim, kierownik Katedry Antropologii i Etnologii.

${ }_{106}$ Witold Taszycki (1898-1979), historyk języka polskiego, w 1925 r. otrzymał habilitację z zakresu językoznawstwa słowiańskiego na Uniwersytecie Jagiellońskim, w 1929 r. przeniósł się do Lwowa, obejmując stanowisko profesora nadzwyczajnego UJK w Katedrze Filologii Słowiańskiej, od 1936 r. profesor zwyczajny, kierownik Katedry Języka Polskiego UJK.

107 Tadeusz Sulimirski (1898-1983), w 1931 r. uzyskał habilitację z zakresu prehistorii ze szczególnym uwzględnieniem ziem polskich. W latach 1931-1935 pełnił obowiązki zastępcy profesora i kierownika Zakładu Prehistorii UJK, od 1935 r. adiunkt przy Katedrze Prehistorii. W 1937 r. mianowany profesorem nadzwyczajnym prehistorii na Wydziale Filozoficznym Uniwersytetu Jagiellońskiego.

108 Adam Fischer (1889-1943), etnograf i etnolog, od 1921 r. docent etnologii na Uniwersytecie Lwowskim, w 1930 r. profesor zwyczajny UJK. 
30. ZNiO, rkps Ossol. 7343/II, k. 353

Lwów, 27 V 1933 r.

Kochany Staszku!

Już po naszej rozmowie przypomniałem sobie, żeby Cię poprosić, abyś postawił na porządku dziennym Komisji hist[orycznej] Wydz[iału] Hum[anistycznego] także sprawę reformy studiów historycznych, chciałbym abyście wypowiedzieli i poprawili mój projekt (według Kwart[alnika] Histor[ycznego] ${ }^{109}$.

A przynajmniej, abyście przeprowadzili przez Wydział wezwanie do Ministerstwa, aby zwołano konferencję w tej sprawie we wrześniu.

Skoro Cię już nie zastałem, piszę. Tymczasem do widzenia, piękne ukłony dla Pani, oddany

Franek Bujak

\section{Bibliografia}

Adamus J., Stanistaw Zakrzewski wobec problemu ideologii ustrojowej, „Przewodnik Historyczno-Prawny" 1937, s. 73-78.

Błachowska K., Stanisław Zakrzewski (1873-1936), w: Złota księga historiografii lwowskiej XIX i XX wieku, red. J. Maternicki, współpr. L. Zaszkilniak, Rzeszów 2007, s. 379-397.

Budzyński Z., Franciszek Bujak (1875-1953), w: Złota księga historiografii lwowskiej XIX i XX wieku, red. J. Maternicki, współpr. L. Zaszkilniak, Rzeszów 2007, s. 421-440.

Budzyński Z., Szkoła historii społeczno-gospodarczej Franciszka Bujaka na Uniwersytecie Jana Kazimierza we Lwowie, w: Wielokulturowe środowisko historyczne Lwowa w XIX i XX w., t. 2, red. J. Maternicki, L. Zaszkilniak, Rzeszów 2004, s. 309-328.

Dąbkowski P., Profesor Stanistaw Zakrzewski. Jego praca w Towarzystwie Naukowem Lwowskiem, „Sprawozdanie Towarzystwa Naukowego we Lwowie" 1936, nr 1, s. 99-108.

Franaszek P., Bujakowska koncepcja badania dziejów gospodarczych ziem polskich „Badania z Dziejów Społecznych $i$ Gospodarczych” $i$ Informator statystyczny do dziejów społeczno-gospodarczych Galicji, w: Celem nauki jest człowiek... Studia z historii spotecznej $i$ gospodarczej ofiarowane Helenie Madurowicz-Urbańskiej, Kraków 2000, s. 37-46.

${ }^{109}$ F. Bujak, Reforma studiów historycznych na Uniwersytecie $z$ punktu widzenia przygotowania do zawodu nauczycielskiego. Odczyt wygłoszony na posiedzeniu Sekcji Dydaktycznej Oddziatu Polskiego Towarzystwa Historycznego we Lwowie dnia 10 lutego 1933 r., „Wiadomości Historyczno-Dydaktyczne” 1933, nr 1, s. 1-21 (odb.). 
Grabski A.F., Franciszek Bujak i historia gospodarcza (uwagi o metodologicznych pogladach uczonego), „Historyka” 9, 1979, s. 101-124.

Handelsman M., Stanistaw Zakrzewski 1873-1936, „Droga” 16, 1937, s. 420-430.

Inglot S., Badania $z$ zakresu dziejów społecznych $i$ gospodarczych $w$ Polsce 1918-1930, „Wiadomości Historyczne” 1933, nr 2, s. 81-111, 153-178.

Inglot S., Franciszek Bujak. Działalność naukowa i dydaktyczna, Wrocław 1955.

Janeczek A., Franciszek Bujak: historyk w nurcie życia, w: F. Bujak, Studia nad osadnictwem Małopolski, Poznań 2001, s. 207-233.

Madurowicz-Urbańska H., Franciszek Bujak-o nowy ksztatt historii, w: F. Bujak, Wybór pism, t. 1, Warszawa 1976 (wyd. 2, Kraków 2001).

Madurowicz-Urbańska H., Franciszek Bujak 1875-1953, w: Uniwersytet Jagielloński. Złota Księa Wydziału Historycznego, red. J. Dybiec, Kraków 2000, s. 208-211.

Maternicki J., U progu niepodlegtości, w: tenże, Historia $i$ życie narodu. Poglady i postawy historyków polskich XIX $i$ XX w., Rzeszów 2009, s. 304-314.

Modelski T.E., Działalność naukowa Ś.p. Stanisława Zakrzewskiego, Lwów 1936.

Pawelec T., Trzy wizje dziejów - F. Bujak, M. Handelsman, J. Rutkowski, w: Środowiska historyczne II Rzeczypospolitej, cz. 5, red. J. Maternicki, Warszawa 1990, s. 166-186.

Pisulińska J., Zagadnienie syntezy $w$ refleksji metodologicznej $i$ dziejopisarstwie Stanisława Zakrzewskiego, w: Badacze przeszłości wobec wyzwań XIX-XXI wieku, red. K. Błachowska, Z. Romek, M. Wolniewicz, Warszawa 2013, s. 213-227.

Shelton A.K., The Democratic Idea in Polish History and Historiography: Franciszek Bujak (1875-1953), Boulder 1989.

Szafraniec B., Franciszek Bujak (1875-1953). Życie, działalność naukowo-dydaktyczna i spoteczna, Toruń 2009.

Śreniowska K., Stanisław Zakrzewski. Przyczynek do charakterystyki pradów ideologicznych w historiografii polskiej 1893-1936, Łódź 1956.

Tyszkiewicz J., Stanistaw Zakrzewski byt nie tylko mediewista, w: Środowiska historyczne II Rzeczypospolitej, cz. 3, red. J. Maternicki, Warszawa 1989, s. 119-131.

Tyszkowski K., Stanistaw Zakrzewski (Wspomnienia pośmiertne), „Nowe Czasy” 1936, nr 6, s. 3.

Włodarski B., Zarys biograficzny (Stanistawa Zakrzewskiego), w: S. Zakrzewski, Zagadnienia historyczne, t. 1, Lwów 1936, s. VII-XVI.

Wójcik-Łagan H., Franciszek Bujak jako dydaktyk historii, w: Wielokulturowe środowisko historyczne Lwowa $w$ XIX $i$ XX w., t. 5, red. J. Maternicki, L. Zaszkilniak, Rzeszów 2007, s. 500-510.

Zajączkowski S., Stanisław Zakrzewski 1873-1936, „Ateneum Wileńskie” 1936, s. 905-944. 
Joanna Pisulińska

On friendship and historical sciences. Letters from Franciszek Bujak to Stanisław Zakrzewski in the collection of the Library of the National

Ossolineum Institute in Wrocław

(Summary)

The collection of the Library of the National Ossolineum Institute in Wrocław includes many interesting pieces of correspondence sent by prominent scholars (mostly historians) to Stanisław Zakrzewski (1873-1936) - well-known and highly esteemed interwar historian from Lviv, politician, active member of numerous academic institutions and associations. The collection also contains an edited set of letters penned in the years 1902-1933 by Franciszek Bujak (1875-1953), prominent researcher of social and economic history. The two scholars first met ca. 1895, participating in various events such as the historical seminars hosted by Stanisław Smolka and Wincenty Zakrzewski at the Jagiellonian University. They remained friends for many years, until Zakrzewski's death in 1936. Since 1920, both researchers worked at the John Casimir University in Lviv. In his letters, F. Bujak mostly wrote to his friend about personal matters and shared his thoughts on various academic and organizational topics.

Joanna Pisulińska - dr hab., prof. Uniwersytetu Rzeszowskiego, kierownik Zakładu Historii Historiografii i Metodologii Historii UR. Zajmuje się dziejami polskiej historiografii XIX i XX w. Autorka wielu publikacji, m.in. monografii: Żydzi w polskiej myśli historycznej doby porozbiorowej (1795-1914). Syntezy, parasyntezy i podręczniki dziejów ojczystych, Rzeszów 2004; Lwowskie środowisko historyczne w okresie międzywojennym (1918-1939), Rzeszów 2012.

Joanna Pisulińska - dr hab., prof. UR, head of the Department of History of Historiography and Methodology of History, University of Rzeszów. She deals with the history of Polish historiography of the nineteenth and the twentieth century. Author of a number of publications, including the monographs $\dot{Z} y d z i$ $w$ polskiej myśli historycznej doby porozbiorowej (1795-1914). Syntezy, parasyntezy i podręczniki dziejów ojczystych, Rzeszów 2004; Lwowskie środowisko historyczne w okresie międzywojennym (1918-1939), Rzeszów 2012.

E-mail: jpisulinska@wp.pl. 